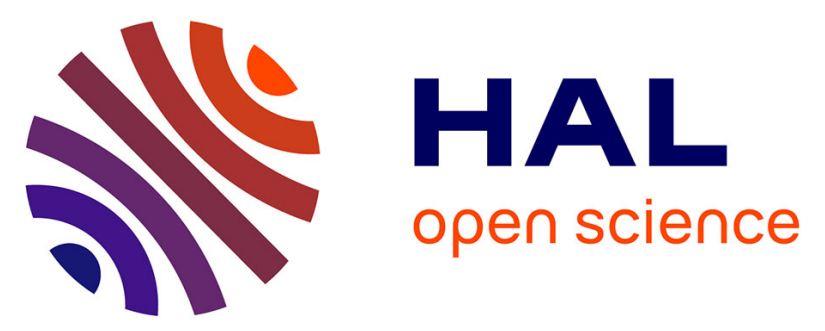

\title{
Guanidinium Alkynesulfonates with Single-Layer Stacking Motif: Interlayer Hydrogen Bonding Between Sulfonate Anions Changes the Orientation of the Organosulfonate R Group from "Alternate Side" to "Same Side"
}

Karim Bouchmella, Sylvain G. Dutremez, Christian Guerin, Jean-Christophe Longato, Francoise Dahan

\section{- To cite this version:}

Karim Bouchmella, Sylvain G. Dutremez, Christian Guerin, Jean-Christophe Longato, Francoise Dahan. Guanidinium Alkynesulfonates with Single-Layer Stacking Motif: Interlayer Hydrogen Bonding Between Sulfonate Anions Changes the Orientation of the Organosulfonate R Group from "Alternate Side" to "Same Side". Chemistry - A European Journal, 2010, 16 (8), pp.2528 - 2536. 10.1002/chem.200901717 . hal-00566181

\author{
HAL Id: hal-00566181 \\ https://hal.science/hal-00566181
}

Submitted on 15 Feb 2011

HAL is a multi-disciplinary open access archive for the deposit and dissemination of scientific research documents, whether they are published or not. The documents may come from teaching and research institutions in France or abroad, or from public or private research centers.
L'archive ouverte pluridisciplinaire HAL, est destinée au dépôt et à la diffusion de documents scientifiques de niveau recherche, publiés ou non, émanant des établissements d'enseignement et de recherche français ou étrangers, des laboratoires publics ou privés. 
Guanidinium Alkynesulfonates with Single Layer Stacking Motif: Interlayer Hydrogen Bonding Between Sulfonate Anions Changes the Orientation of the Organosulfonate R Group from "Alternate Side" to "Same Side"

Karim Bouchmella ${ }^{[a]}$ Sylvain G. Dutremez, ${ }^{*[a]}$ Christian Guérin ${ }^{[a]}$ JeanChristophe Longato, ${ }^{[a]}$ and Françoise Dahan ${ }^{[b]}$

[a] K. Bouchmella, Dr. S. G. Dutremez, Prof. Dr. C. Guérin, J.-C. Longato Institut Charles Gerhardt Montpellier, UMR 5253 CNRS-UM2-ENSCM-UM1 Equipe CMOS

Université Montpellier II

Bât. 17, CC 1701

Place Eugène Bataillon

34095 Montpellier Cedex 5 (France)

Fax: (+33) 4-67-14-38-52

E-mail: dutremez@univ-montp2.fr

[b] Dr. F. Dahan

Laboratoire de Chimie de Coordination du CNRS, UPR 8241

Liée par conventions à l'Université Paul Sabatier et à l'Institut

National Polytechnique de Toulouse

205 route de Narbonne

31077 Toulouse Cedex 4 (France) 
Abstract: Acetylenic sulfonic acids $\mathrm{HC} \equiv \mathrm{CSO}_{3} \mathrm{H} \cdot 2.33 \mathrm{H}_{2} \mathrm{O}(3)$ and $\mathrm{CH}_{3} \mathrm{C} \equiv \mathrm{CSO}_{3} \mathrm{H} \cdot 1.88 \mathrm{H}_{2} \mathrm{O}$ (4) were prepared by hydrolysis of $\mathrm{HC} \equiv \mathrm{CSO}_{3} \mathrm{SiMe}_{3}$ (1) and $\mathrm{CH}_{3} \mathrm{C} \equiv \mathrm{CSO}_{3} \mathrm{SiMe}_{3}$ (2). These acids were reacted with guanidinium carbonate to yield $\left[{ }^{+} \mathrm{C}\left(\mathrm{NH}_{2}\right)_{3}\right]\left[\mathrm{HC} \equiv \mathrm{CSO}_{3}{ }^{-}\right]$(5) and $\left[{ }^{+} \mathrm{C}\left(\mathrm{NH}_{2}\right)_{3}\right]\left[\mathrm{CH}_{3} \mathrm{C} \equiv \mathrm{CSO}_{3}{ }^{-}\right](\mathbf{6})$. Compounds 1-6 were characterized by spectroscopic methods, and the X-ray crystal structures of the guanidinium salts were determined. The X-ray results of 5 show that the guanidinium cations and organosulfonate anions associate into 1D ribbons through $\mathrm{R}_{2}^{2}(8)$ dimer interactions whereas association of these ions in $\mathbf{6}$ is achieved through $\mathrm{R}_{2}{ }^{2}(8)$ and $\mathrm{R}_{2}{ }^{1}(6)$ interactions. The ribbons in $\mathbf{5}$ associate into 2D sheets through $\mathrm{R}_{2}{ }^{2}(8)$ dimer interactions and $\mathrm{R}_{6}{ }^{3}(12)$ rings whereas those in $\mathbf{6}$ are connected through $\mathrm{R}_{2}{ }^{1}(6)$ and $\mathrm{R}_{2}{ }^{2}(8)$ dimer interactions and $\mathrm{R}_{6}{ }^{4}(14)$ rings. Compound $\mathbf{6}$ exhibits a single layer stacking motif similar to that found in guanidinium alkane- and arenesulfonates, i.e., the alkynyl groups alternate orientation from one ribbon to the next. The stacking motif in $\mathbf{5}$ is also single layer but, due to interlayer hydrogen bonding between sulfonate anions, the alkynyl groups of each sheet all point to the same side of the sheet. 


\section{Introduction}

Hydrogen bonding is nature's favorite way of keeping molecules tightly bound to one another. This is presumably because most organic compounds have sites capable of hydrogen bonding ranging from weakly polarized $\mathrm{C}-\mathrm{H}$ bonds to strongly polarized $\mathrm{OH}$ groups. Its strength depends on the nature of the atoms involved in the A-H $\cdots \mathrm{B}$ connection and, because it is a directional interaction, it is also contingent on the distance between the $\mathrm{H}$ and $\mathrm{B}$ centres and on the A-H-B angle. ${ }^{[1-5]}$

Due to its great versatility, hydrogen bonding has become a key interaction in Crystal Engineering. ${ }^{[6-8]}$ Numerous modules possessing hydrogen bonding capabilities have been described in the literature and used to construct supramolecular assemblies. Guanidinium organosulfonates, $\mathrm{C}\left(\mathrm{NH}_{2}\right)_{3}{ }^{+} \mathrm{RSO}_{3}{ }^{-}$, in which $\mathrm{RSO}_{3}{ }^{-}$may be an alkane- or an arenesulfonate anion, belong to such category. ${ }^{[9-19]}$

Guanidinium sulfonates form robust hydrogen-bonded networks. It was suggested that this is due to a combination of several factors: the large number of strong hydrogen bonds, matched number of donors and acceptors (six guanidinium protons and six electron pairs on the three sulfonate oxygen atoms), 3-fold topologies for both the guanidinium and $\mathrm{RSO}_{3}{ }^{-}$ ions, similar sizes of the two partners, and presence of Coulombic interactions between the oppositely charged ions. ${ }^{[10,12,13]}$ In the solid state, guanidinium cations and organosulfonate anions are tightly bonded through $\mathrm{R}_{2}{ }^{2}(8)$ dimer interactions. ${ }^{[20]}$ Repetition of this associative sequence along an axis results in the formation of infinite ribbons (Scheme 1). Association of these $1 \mathrm{D}$ ribbons through $\mathrm{R}_{2}{ }^{2}(8)$ dimer interactions and $\mathrm{R}_{6}{ }^{3}(12)$ rings in a direction perpendicular to the first one generates $2 \mathrm{D}$ sheets made of quasihexagonal patterns. This "honeycomb" structure appears to be general and has been observed for most guanidinium monosulfonates.

\section{Scheme 1 , here}

The "honeycomb" structure is not perfectly flat but is puckered. The degree of puckering, as measured by the $\theta_{\mathbb{R}}$ angle made by two adjacent ribbons (Scheme 1), is a function of the size of the $\mathrm{R}$ group of the sulfonate anion. For small $\mathrm{R}$ groups, corrugation is not severe and $\theta_{\mathrm{IR}}$ is close to $180^{\circ}$. In this case, all of the $\mathrm{R}$ groups within a sheet are oriented to the same side of the sheet. For bulky $\mathrm{R}$ groups, $\theta_{\mathbb{I R}}$ may be as low as $77^{\circ} .^{[12]}$ In this case, $\mathrm{R}$ groups within a sheet are not oriented to the same side of the sheet and alternate orientation from one ribbon to the next. Thus, the hydrogen-bonded sheet structure is preserved no matter 
what the size of the $\mathrm{RSO}_{3}{ }^{-}$anion, demonstrating the adaptability of the guanidinium sulfonate network.

The 2D sheets pile up in the third dimension according to two different motifs (Scheme 1). ${ }^{[9,11-13]}$ If the alkane or arene groups of the sulfonate anions are small, interdigitation of these groups is possible in the non-polar region separating the sheets, resulting in a bilayer stacking of the sheets. If the $\mathrm{RSO}_{3}{ }^{-}$anions are sterically demanding, interdigitation of the $\mathrm{R}$ groups is not possible, resulting in the formation of single layer motifs.

Structural studies have been carried out on guanidinium arenesulfonates bearing substituents capable of hydrogen bonding. ${ }^{[10,13]}$ These substituents were found to interfere with the guanidinium sulfonate hydrogen bond network, leading to severe perturbation, and in some cases disruption of the quasihexagonal structure. The degree of perturbation decreased in the order $\mathrm{COOH}>\mathrm{OH}>\mathrm{NO}_{2}$, in agreement with the ability of these groups to form strong hydrogen bonds.

Another intriguing feature of guanidinium arenesulfonates is their ability to form inclusion compounds when crystallized from certain aromatic solvents. ${ }^{[14,16,19]}$ The bilayer stacking motif observed in guest-free compounds is not encountered in host-guest complexes, presumably because interdigitation of the organosulfonate $\mathrm{R}$ groups in the non-polar region separating the sheets precludes the inclusion of solvent molecules. On the other hand, the single layer structure is observed in which the solvent molecules are interdigitated with the $\mathrm{R}$ groups of the $\mathrm{RSO}_{3}{ }^{-}$anions. Compounds that crystallize with this type of architecture have been termed "continuously layered inclusion compounds" abbreviated CLIC. In these CLIC's the number of guest molecules per guanidinium sulfonate unit is one. Another structural arrangement exists that is found in "tubular inclusion compounds" abbreviated TIC. These TIC's consist of six-sided discrete tubes, each comprising six guanidinium sulfonate ribbons. The tubes assemble into a hexagonal array with the $\mathrm{R}$ groups of the $\mathrm{RSO}_{3}{ }^{-}$anions directed towards the outside of the tubes. There are two thirds of a guest per guanidinium sulfonate unit: one third guest occupies the interior of the tubes and the remaining third is located in the region between the tubes.

The thermal behavior of guanidinium alkylbenzenesulfonates and guanidinium alkylbiphenylsulfonates has been investigated by means of various techniques including polarizing optical microscopy, differential scanning calorimetry, dilatometry, infrared spectroscopy, and X-ray diffraction. ${ }^{[21,22]}$ These compounds turn into persistent smectic 
liquid-crystal phases upon heating, and this phenomenon was ascribed to the reinforcement provided by the hydrogen-bonded network. Furthermore, rheology studies indicated the persistence of intermolecular hydrogen bonding in the liquid crystalline state. ${ }^{[22]}$ Interestingly, unlike sodium alkylbenzenesulfonates, guanidinium alkylbenzenesulfonates also exhibit lyotropic behavior in aqueous and organic solvents, and this discrepancy was attributed to the fact that hydrogen bonding mediated by the guanidinium ion was required for gel formation. ${ }^{[23]}$ Recently, smectic liquid crystalline phases were reported for guanidinium alkanesulfonates. $^{[24]}$

Ward and co-workers also prepared and characterized crystallographically a series of guanidinium $\alpha, \omega$-alkane- and arenedisulfonates and showed that these compounds crystallized with pillared architectures. ${ }^{[25-35]}$ The disulfonate pillars connect opposing hydrogen-bonded sheets, resulting in the formation of cavities between the sheets. When long enough pillars are used, the cavities are sufficiently large to accommodate solvent molecules. In this respect, guanidinium organodisulfonates have been regarded as functional organic zeolite analogues. ${ }^{[36]}$ These clathrates exhibit various kinds of architectures (discrete bilayer, simple brick, crisscross bilayer, double brick, zigzag brick, V-brick) whose topologies are controlled by the size of the pillar and nature of the included guest (size of the molecule and types of functional groups present in it). An interesting application of this work has consisted in the crystallization-based separation of isomeric mixtures of aromatic molecules, ${ }^{[3]}$ and attempts have been made to use these systems for chiral discrimination. ${ }^{[37]}$

Yet, as described previously for guanidinium organomonosulfonates, the guanidinium sulfonate sheet structure of guanidinium organodisulfonates may be disrupted when solvent molecules capable of interacting with these sheets via hydrogen bonding are included in the structure. This turned out to be the case for guanidinium 1,5-naphthalenedisulfonate crystallized in the presence of 2-methoxyethanol. ${ }^{[38]}$ In another connection, the disulfonate anion may sometimes have some other function than just being a pillar between guanidinium sulfonate sheets and, for instance, electrochemical studies have been carried on guanidinium ferrocenedisulfonate adhered to a glassy carbon electrode. ${ }^{[39]}$

In recent years, our research efforts have focused on the preparation, characterization, and study of the polymerisation behavior of symmetrical and unsymmetrical diacetylenes in which heteroelements are attached to the triple bonds. ${ }^{[40-44]}$ In particular, it was found that 1,4bis(triorganosilyl)buta-1,3-diynes and their tin-containing counterparts did not show any solid-state polymerisation activity due to the bulkiness of the end-capping groups and the lack of strong interactions between molecules in the crystal lattice that could bring the $\mathrm{C}_{4}$ rods near 
one another. ${ }^{[44]}$ One way of improving this situation might consist of using guanidinium sulfonates comprising a diacetylenic moiety, and this possibility is currently under investigation in our laboratory. In a parallel study, we decided to investigate guanidinium monoalkynesulfonates because these molecules are simpler models than the diacetylenic ones. ${ }^{[45]}$ We report herein the synthesis and structural characterization of guanidinium sulfonates containing alkyne groups, i.e. $\left[{ }^{+} \mathrm{C}\left(\mathrm{NH}_{2}\right)_{3}\right]\left[\mathrm{HC} \equiv \mathrm{CSO}_{3}{ }^{-}\right] \quad$ (5) and $\left[{ }^{+} \mathrm{C}\left(\mathrm{NH}_{2}\right)_{3}\right]\left[\mathrm{CH}_{3} \mathrm{C} \equiv \mathrm{CSO}_{3}{ }^{-}\right](6)$. It was important to establish whether the $2 \mathrm{D}$ sheet structure found in guanidinium alkane- and arenesulfonates is maintained in these novel salts and determine what kind of arrangement is present in the third dimension. Our results show that a hydrogen-bonded sheet motif made of $\mathrm{R}_{2}{ }^{2}(8)$ and $\mathrm{R}_{6}{ }^{3}(12)$ rings is present in the solid-state structure of 5 and that a sheet motif made of $\mathrm{R}_{2}{ }^{1}(6), \mathrm{R}_{2}{ }^{2}(8)$ and $\mathrm{R}_{6}{ }^{4}(14)$ hydrogen bonding interactions is present in solid $\mathbf{6}$. The 3D structure of $\mathbf{6}$ is the same as that found in Ward's compounds, i.e., it is a "typical" single layer stacking motif. Interestingly, the 3D structure of $\mathbf{5}$ is also a single layer stacking motif, but it differs from that of $\mathbf{6}$ in that the alkynyl groups all point to the same side of the sheet. This unusual arrangement originates from interlayer hydrogen bonding between sulfonate anions. 


\section{Results and Discussion}

Syntheses: $\mathrm{HC} \equiv \mathrm{CSO}_{3} \mathrm{SiMe}_{3}$ (1) is a known compound that was prepared in the past by sulfonation of $\mathrm{HC} \equiv \mathrm{CSiMe}_{3}$ with $\mathrm{ClSO}_{3} \mathrm{SiMe}_{3}$ or by sulfonation of $\mathrm{HC} \equiv \mathrm{CSiMe}_{3}$ with $\mathrm{SO}_{3} \cdot$ dioxane; ${ }^{[46]}$ we have synthesized $\mathbf{1}$ using the former method (Scheme 2). $\mathrm{CH}_{3} \mathrm{C} \equiv \mathrm{CSO}_{3} \mathrm{SiMe}_{3}$ (2) was synthesized by sulfonation of $\mathrm{CH}_{3} \mathrm{C} \equiv \mathrm{CSiMe}_{3}$ with $\mathrm{SO}_{3}$.dioxane (Scheme 2). $\mathrm{ClSO}_{3} \mathrm{SiMe}_{3}$ and $\mathrm{SO}_{3}$.dioxane were prepared as described in the literature. ${ }^{[46]}$

\section{Scheme 2, here}

Sulfonic acids $\mathrm{HC} \equiv \mathrm{CSO}_{3} \mathrm{H}$ and $\mathrm{CH}_{3} \mathrm{C} \equiv \mathrm{CSO}_{3} \mathrm{H}$ were prepared by hydrolysis of $\mathbf{1}$ and $\mathbf{2}$, respectively (Scheme 3). These acids were isolated as hydrates. ${ }^{1} \mathrm{H}$ NMR spectroscopy and elemental analysis showed the compositions of the two acids to be $\mathrm{HC} \equiv \mathrm{CSO}_{3} \mathrm{H} \cdot 2.33 \mathrm{H}_{2} \mathrm{O}(3)$ and $\mathrm{CH}_{3} \mathrm{C} \equiv \mathrm{CSO}_{3} \mathrm{H} \cdot 1.88 \mathrm{H}_{2} \mathrm{O}$ (4). The composition of 3 is close to the $\mathrm{HC} \equiv \mathrm{CSO}_{3} \mathrm{H} \cdot 2.5 \mathrm{H}_{2} \mathrm{O}$ stoichiometry found by Mérault. ${ }^{[46]}$ The composition of $\mathbf{4}$ is similar to the $\left(\mathrm{CH}_{3}\right)_{3} \mathrm{SiC} \equiv \mathrm{CSO}_{3} \mathrm{H} \cdot 2 \quad \mathrm{H}_{2} \mathrm{O}$ stoichiometry reported by Calas and Bourgeois. ${ }^{[47]}$ $\left[{ }^{+} \mathrm{C}\left(\mathrm{NH}_{2}\right)_{3}\right]\left[\mathrm{HC} \equiv \mathrm{CSO}_{3}{ }^{-}\right](\mathbf{5})$ and $\left[{ }^{+} \mathrm{C}\left(\mathrm{NH}_{2}\right)_{3}\right]\left[\mathrm{CH}_{3} \mathrm{C} \equiv \mathrm{CSO}_{3}{ }^{-}\right](\mathbf{6})$ were synthesized by allowing acids $\mathbf{3}$ and $\mathbf{4}$ to react with stoichiometric amounts of guanidinium carbonate (Scheme 3).

Scheme 3, here

Molecular dimensions: X-ray quality crystals of $\mathbf{5}$ and $\mathbf{6}$ were obtained by dissolving these salts in water and allowing the solutions to come slowly to dryness. It is noteworthy that water molecules are not present in the structures of $\mathbf{5}$ and $\mathbf{6}$; this situation appears to be general and has been observed for most guanidinium monosulfonates described by Ward. This is presumably because the energy penalty for the disruption of the hydrogen bond network of guanidinium sulfonates by water molecules is too high. However, one exception has been reported which is guanidinium 2,4-dinitrobenzenesulfonate monohydrate. ${ }^{[13,15]}$

Guanidinium 1-propynesulfonate (6) crystallizes in the centrosymmetric space group Pnma with $Z=12$. One molecule in the cell occupies a general position and the other molecule lies on a mirror plane. The geometrical parameters of the crystallographically unique guanidinium cations and sulfonate groups are very much like those found in Ward's compounds: the C-N bond distances are in the range 1.3195(12)-1.3269(10) $\AA$ and the N-C-N angles lie between 119.11(11) and $120.44(6)^{\circ}$. The S-O bond distances span the range 1.4462(10)-1.4546(6) $\AA$ and the O-S-O angles the range $112.78(4)-113.31(4)^{\circ}$. The $\mathrm{C} \equiv \mathrm{C}$ distances are those typically found in alkynes, i.e. 1.1954(13) and 1.2062(18) A. The S-C distances are 1.7086(9) and 1.7148(13) $\AA$. The $\mathrm{S}-\mathrm{C} \equiv \mathrm{C}$ angles are close to $180^{\circ}$ and so are the 
$\mathrm{C} \equiv \mathrm{C}-\mathrm{CH}_{3}$ angles, i.e., $177.22(9)$ and $176.07(12)^{\circ}$ for $\mathrm{S}-\mathrm{C} \equiv \mathrm{C}$ and $179.67(12)$ and $178.90(15)^{\circ}$ for $\mathrm{C} \equiv \mathrm{C}-\mathrm{CH}_{3}$.

Guanidinium ethynesulfonate (5) crystallizes in the noncentrosymmetric space group $P 6_{3}$ with $Z=6$. There is one crystallographically unique molecule in the cell. The geometrical parameters of the guanidinium cation are slightly different from those of $\mathbf{6}$ : there is one short C-N bond distance (1.3232(12) $\AA$ ) and two longer ones (1.3386(11) and 1.3460(12) $\AA$ ), indicating a slight dissymmetry in the guanidinium cation. Although this situation is not common, it is not unusual and has been observed previously in the X-ray crystal structure of guanidinium methanesulfonate. ${ }^{[9]}$ Slight differences are also observed in the N-C-N angles, one angle $\left(117.95(6)^{\circ}\right)$ being much smaller than the other two $\left(119.20(4)\right.$ and $\left.119.63(3)^{\circ}\right)$. The average $\mathrm{N}-\mathrm{C}-\mathrm{N}$ angle is $118.93^{\circ}$. The $\mathrm{S}-\mathrm{O}$ bond distances are slightly longer than those observed in 6 and span the range 1.4582(11)-1.4661(11) A. The O-S-O angles are all smaller than those of 6: 110.05(7), 111.19(7), and 111.55(6) ${ }^{\circ}$. The $C \equiv C$ distance (1.194(2) $\AA$ ) and SC bond length $(1.7169(19) \AA)$ compare favorably with the values found in the 1propynesulfonate salt. The $\mathrm{S}-\mathrm{C} \equiv \mathrm{C}$ angle $\left(175.06(14)^{\circ}\right)$ deviates slightly from the expected $180^{\circ}$ value.

2D structures: Unlike the situation commonly observed in guanidinium alkane- and arenesulfonates, ${ }^{[15]}$ the guanidinium cations and sulfonate anions in solid $\mathbf{6}$ assemble into 1D ribbons through $\mathrm{R}_{2}{ }^{2}(8)$ and $\mathrm{R}_{2}{ }^{1}(6)$ dimer interactions (Figure 1). This is due to the fact that, in each ribbon, every third sulfonate anion has undergone a 60-degree-rotation with respect to the two preceding ones. There are six unique $\mathrm{N}-\mathrm{H} \cdots \mathrm{O}$ hydrogen bonds in each ribbon with geometries similar to those observed in Ward's compounds: ${ }^{[9-11]}$ two of them are involved in a $\mathrm{R}_{2}{ }^{1}(6)$ dimer interaction and four of them in $\mathrm{R}_{2}{ }^{2}(8)$ interactions. The $\mathrm{H} \cdots \mathrm{O}$ distances in the $\mathrm{R}_{2}{ }^{1}(6)$ ring are $2.16(\mathrm{H}(1 \mathrm{~A}) \cdots \mathrm{O}(5))$ and $2.14 \AA(\mathrm{H}(3 \mathrm{~A}) \cdots \mathrm{O}(5))$, and the corresponding $\mathrm{N} \cdots \mathrm{O}$ distances are 2.9437(11) $(\mathrm{N}(1) \cdots \mathrm{O}(5))$ and 2.9315(11) $\AA(\mathrm{N}(3) \cdots \mathrm{O}(5))$. The $\mathrm{N}-\mathrm{H} \cdots \mathrm{O}$ angles are alike but differ significantly from the optimum $180^{\circ}$ value: $\angle \mathrm{N}(1)-\mathrm{H}(1 \mathrm{~A}) \cdots \mathrm{O}(5)=148.1$ and $\angle \mathrm{N}(3)-\mathrm{H}(3 \mathrm{~A}) \cdots \mathrm{O}(5)=148.9^{\circ}$. The $\mathrm{H} \cdots \mathrm{O}$ distances in the $\mathrm{R}_{2}^{2}(8)$ rings are 2.10 $(\mathrm{H}(1 \mathrm{~B}) \cdots \mathrm{O}(1)), 2.15(\mathrm{H}(2 \mathrm{~B}) \cdots \mathrm{O}(3)), 2.22(\mathrm{H}(4 \mathrm{~A}) \cdots \mathrm{O}(3))$, and $2.09 \AA(\mathrm{H}(5 \mathrm{~A}) \cdots \mathrm{O}(2))$. The corresponding $\mathrm{N} \cdots \mathrm{O}$ distances are 2.9727(19) $(\mathrm{N}(1) \cdots \mathrm{O}(1)), 3.0222(10)(\mathrm{N}(2) \cdots \mathrm{O}(3))$, $3.0685(10)(\mathrm{N}(4) \cdots \mathrm{O}(3))$, and 2.9645(8) $\AA(\mathrm{N}(5) \cdots \mathrm{O}(2))$. The $\mathrm{N}-\mathrm{H} \cdots \mathrm{O}$ angles are 169.3 $(\mathrm{N}(1)-\mathrm{H}(1 \mathrm{~B}) \cdots \mathrm{O}(1)), 173.7(\mathrm{~N}(2)-\mathrm{H}(2 \mathrm{~B}) \cdots \mathrm{O}(3)), 161.1(\mathrm{~N}(4)-\mathrm{H}(4 \mathrm{~A}) \cdots \mathrm{O}(3))$, and $173.2^{\circ}$ $(\mathrm{N}(5)-\mathrm{H}(5 \mathrm{~A}) \cdots \mathrm{O}(2))$. These angles are a lot closer to the optimum $180^{\circ}$ angle, suggesting that 
hydrogen bonds involved in $\mathrm{R}_{2}^{2}(8)$ dimer interactions are stronger than those involved in $\mathrm{R}_{2}{ }^{1}(6)$ interactions.

Figure 1, here

The guanidinium sulfonate ribbons assemble into $2 \mathrm{D}$ sheets through $\mathrm{R}_{2}{ }^{1}(6), \mathrm{R}_{2}{ }^{2}(8)$, and $\mathrm{R}_{6}{ }^{4}(14)$ rings; typically observed $\mathrm{R}_{6}{ }^{3}(12)$ rings are not present. The hydrogen-bonded sheets lie in the $b c$ plane. There are three unique inter-ribbon hydrogen bonds: one of them is involved in $\mathrm{R}_{2}{ }^{1}(6)$ dimer interaction and two of them in $\mathrm{R}_{2}{ }^{2}(8)$ interaction. The hydrogen bond distance in the $\mathrm{R}_{2}{ }^{1}(6)$ ring is $2.17 \AA(\mathrm{H}(4 \mathrm{~B}) \cdots \mathrm{O}(4))$, and those in the $\mathrm{R}_{2}{ }^{2}(8)$ ring are 2.15 $(\mathrm{H}(2 \mathrm{~A}) \cdots \mathrm{O}(1))$ and $2.11 \AA(\mathrm{H}(3 \mathrm{~B}) \cdots \mathrm{O}(2))$. The corresponding $\mathrm{N} \cdots \mathrm{O}$ distances are $2.9467(12)(\mathrm{N}(4) \cdots \mathrm{O}(4)), 3.0284(11)(\mathrm{N}(2) \cdots \mathrm{O}(1))$, and 2.9736(11) $\AA(\mathrm{N}(3) \cdots \mathrm{O}(2))$. The N$\mathrm{H} \cdots \mathrm{O}$ angles are $146.3(\mathrm{~N}(4)-\mathrm{H}(4 \mathrm{~B}) \cdots \mathrm{O}(4)), 172.8(\mathrm{~N}(2)-\mathrm{H}(2 \mathrm{~A}) \cdots \mathrm{O}(1))$, and $168.5^{\circ}(\mathrm{N}(3)-$ $\mathrm{H}(3 \mathrm{~B}) \cdots \mathrm{O}(2))$. Once again, hydrogen bonds involved in $\mathrm{R}_{2}{ }^{2}(8)$ dimer interactions appear to be stronger than those involved in $\mathrm{R}_{2}{ }^{1}(6)$ interactions, as indicated by the higher values of the $\mathrm{N}-\mathrm{H} \cdots \mathrm{O}$ angles.

As seen in Figure 2, the alkynyl groups within a hydrogen-bonded sheet of 6 alternate orientation from one ribbon to the next; the stacking motif is thus single layer. This situation is unusual as it is generally observed for guanidinium organosulfonates with large $\mathrm{R}$ groups. The amount of puckering of the sheets, as quantified by the dihedral angle $\theta_{\mathbb{I R}}$ between the least-squares plane of one ribbon and the least-squares plane of an adjacent ribbon, is $151^{\circ}$ $\left(\theta_{\mathbb{R}}=180^{\circ}\right.$ means no puckering). This low degree of puckering likely arises from the small steric demand of the alkynyl group. Guanidinium organosulfonates with similar $\theta_{\mathrm{IR}}$ values and known to crystallize with a single layer stacking motif include guanidinium 1butanesulfonate $\left(157^{\circ}\right)$, guanidinium ferrocenesulfonate $\left(153^{\circ}\right)$, and guanidinium 5-benzoyl4-hydroxy-2-methoxybenzenesulfonate $\left.\quad\left(165^{\circ}\right) .{ }^{[9},{ }^{11-13}\right] \quad$ Generally, guanidinium organosulfonates with a single layer structure exhibit $\theta_{\mathbb{I R}}$ angles that are much smaller (51$\left.122^{\circ}\right) .{ }^{[9,10,12,13]}$

Figure 2, here

The guanidinium cations and ethynesulfonate anions in solid 5 assemble into 1D ribbons through $\mathrm{R}_{2}{ }^{2}(8)$ dimer interactions, as is normally the case in guanidinium alkane- and arenesulfonates. The ribbons assemble into $2 \mathrm{D}$ sheets through $\mathrm{R}_{2}{ }^{2}(8)$ and $\mathrm{R}_{6}{ }^{3}(12)$ rings (Figure 3). There are six unique $\mathrm{N}-\mathrm{H} \cdots \mathrm{O}$ hydrogen bonds in each sheet. The $\mathrm{H} \cdots \mathrm{O}$ distances are $2.10(\mathrm{H}(3 \mathrm{~B}) \cdots \mathrm{O}(2)), 2.26(\mathrm{H}(2 \mathrm{~A}) \cdots \mathrm{O}(3)$ and $\mathrm{H}(3 \mathrm{~A}) \cdots \mathrm{O}(3)), 2.34(\mathrm{H}(2 \mathrm{~B}) \cdots \mathrm{O}(1)), 2.36$ $(\mathrm{H}(1 \mathrm{~B}) \cdots \mathrm{O}(1))$, and $2.50 \AA(\mathrm{H}(1 \mathrm{~A}) \cdots \mathrm{O}(2))$. The corresponding $\mathrm{N} \cdots \mathrm{O}$ distances are 
2.9713(14) $(\mathrm{N}(3) \cdots \mathrm{O}(2)), 3.1348(15)(\mathrm{N}(2) \cdots \mathrm{O}(3)), 3.1353(15)(\mathrm{N}(3) \cdots \mathrm{O}(3)), 3.1464(19)$ $(\mathrm{N}(2) \cdots \mathrm{O}(1)), 3.2385(17)(\mathrm{N}(1) \cdots \mathrm{O}(1))$, and 3.3735(19) $\AA(\mathrm{N}(1) \cdots \mathrm{O}(2))$. The values of the $\mathrm{N}-\mathrm{H} \cdots \mathrm{O}$ angles are all very similar except one: $170.4(\mathrm{~N}(3)-\mathrm{H}(3 \mathrm{~B}) \cdots \mathrm{O}(2)), 171.5(\mathrm{~N}(2)-$ $\mathrm{H}(2 \mathrm{~A}) \cdots \mathrm{O}(3)), \quad 172.2 \quad(\mathrm{~N}(3)-\mathrm{H}(3 \mathrm{~A}) \cdots \mathrm{O}(3)), \quad 152.5 \quad(\mathrm{~N}(2)-\mathrm{H}(2 \mathrm{~B}) \cdots \mathrm{O}(1)), 174.9 \quad(\mathrm{~N}(1)-$ $\mathrm{H}(1 \mathrm{~B}) \cdots \mathrm{O}(1))$, and $170.9^{\circ}(\mathrm{N}(1)-\mathrm{H}(1 \mathrm{~A}) \cdots \mathrm{O}(2))$.

Figure 3, here

The alkynyl groups within a hydrogen-bonded sheet of $\mathbf{5}$ do not alternate sides from ribbon to ribbon. This stacking motif is reminiscent of a bilayer structure. However, the absence of polar regions between the sheets points to a single layer structure. The hydrogenbonded sheets of 5 lie in the $a b$ plane (Figure 4). The amount of puckering is nil. A $\theta_{\mathbb{I R}}$ angle of $180^{\circ}$ has been observed in guanidinium methanesulfonate, guanidinium triflate, guanidinium ethanesulfonate, and guanidinium 2- and 3-nitrobenzenesulfonates; these salts all crystallize with a bilayer stacking motif. ${ }^{[9,12,13]}$

\section{Figure 4, here}

3D structures: The hydrogen-bonded sheets in 6 pile up along $a$ with no polar region between the sheets, as is normally found in guanidinium organosulfonates with a single layer structure (Figure 2). The sheets are highly interdigitated. The amount of interdigitation between the $\mathrm{i}$ and $\mathrm{i}-1$ (or $\mathrm{i}$ and $\mathrm{i}+1$ ) sheets, as estimated by adding the distance between the sulfur atom and the methyl carbon to the distance between the methyl carbon and the midpoint of the $\mathrm{C} \equiv \mathrm{C}$ bond, amounts to $6.4 \AA$. The separation between two successive ( $\mathrm{i}$ and $\mathrm{i}+1$, for instance) hydrogen bonded sheets, roughly equivalent to the distance between the sulfur atom and the midpoint of the $\mathrm{C} \equiv \mathrm{C}$ bond, is $2.3 \AA$. Consequently, no sizeable voids are present in the solid and a compact structure is obtained $\left(\rho_{\text {calcd }}=1.474 \mathrm{~g} \mathrm{~cm}^{-3}\right)$. This arrangement is also an ideal one to maximize $\mathrm{N}-\mathrm{H} \cdots \pi$ interactions between guanidinium cations and acetylenic moieties. Indeed, close examination of the X-ray crystal structure indicates that there are numerous $\mathrm{N}-\mathrm{H} \cdots \pi$ contacts (Figure 5). There are eighteen $\mathrm{H}_{\text {guanidinium }} \cdots \mathrm{C}_{\mathrm{sp}}$ distances ranging from $2.6766 \AA$ to $3.1540 \AA$, and twelve of them are below $3 \AA$. The $\mathrm{N}-\mathrm{H} \cdots \mathrm{C}_{\mathrm{sp}}$ angles span the range $92.10-116.54^{\circ}$. Clearly, these interactions are weak. However, their large number suggests that their contribution to stabilization of the structure is not negligible. Literature concerning $\mathrm{N}-\mathrm{H} \cdots \mathrm{C} \equiv \mathrm{C}$ interactions in small molecules is scarce. Yet, such an interaction has been observed in 1-(2'-aminophenyl)-2-(2',nitrophenyl)ethyne. ${ }^{[4,48]}$ In this compound, one amino hydrogen interacts with the nearby triple bond. It is an intramolecular $\mathrm{N}-\mathrm{H} \cdots \mathrm{C} \equiv \mathrm{C}$ hydrogen bond bifurcated by an intramolecular 
$\mathrm{N}-\mathrm{H} \cdots \mathrm{O}_{2} \mathrm{~N}$ interaction. The $\mathrm{N}-\mathrm{H} \cdots \mathrm{C}_{\mathrm{sp}}$ distances are 2.38 and $2.72 \AA$ and the distance between the hydrogen and the midpoint of the $\mathrm{C} \equiv \mathrm{C}$ bond is $2.49 \AA$; the angle between the $\mathrm{N}-\mathrm{H}$ direction and an axis passing through the $\mathrm{N}-\mathrm{H}$ hydrogen and the centre of the $\mathrm{C} \equiv \mathrm{C}$ bond is $117^{\circ} .{ }^{[4]}$ Thus, the $\mathrm{N}-\mathrm{H} \cdots \mathrm{C}_{\mathrm{sp}}$ distances in 6 are longer than those observed in 1-(2'aminophenyl)-2-(2' '-nitrophenyl)ethyne and the $\mathrm{N}-\mathrm{H} \cdots \mathrm{C}_{\mathrm{sp}}$ angles are smaller, suggestive of weaker $\mathrm{N}-\mathrm{H} \cdots \mathrm{C} \equiv \mathrm{C}$ interactions in the former compound.

Figure 5, here

Other interdigitation schemes are possible that were not observed in the solid-state structure of $\mathbf{6}$ for the following reasons: the first possibility is that the sheets be not interdigitated at all. This situation would be unfavorable because large voids would be created in the structure and steric repulsion between methyl groups in the nonpolar region between the sheets would be substantial. The second conceivable situation is that the amount of interdigitation be half the length of the 1-propynesulfonate anion, i.e. $2.2 \AA$. In this case, voids in the structure would be reduced and steric repulsion between methyl groups would be nil. However, this situation would not take advantage of the stabilizing $\mathrm{N}-\mathrm{H} \cdots \mathrm{C} \equiv \mathrm{C}$ interactions mentioned earlier. A third possible scenario is that the amount of interdigitation be equal to the full length of the 1-propynesulfonate anion, i.e. $4.4 \AA$. In this case, the sheet structure would be disrupted because the methyl groups would be interfering with the guanidinium sulfonate hydrogen bond network.

The 3D structure of $\mathbf{5}$ is also single layer as there is no polar region between the sheets (Figure 4). The hydrogen bonded sheets all have ethynyl moieties pointing in the same direction; there is no up-down-up-down alternation. The structure may be regarded as a bilayer structure in which every other layer has been turned around. The hydrogen bonded sheets pile up along $c$. The amount of interdigitation between the $\mathrm{i}$ and $\mathrm{i}-1$ sheets is quite small and is estimated to be about $1 \AA$, i.e. the length of the $\mathrm{C}_{\mathrm{sp}}-\mathrm{H}$ bond. What is causing this unusual situation is evident from Figure 6: every sulfonate anion from an i layer interacts via a $\mathrm{C}_{\mathrm{sp}}-\mathrm{H} \cdots \mathrm{O}$ hydrogen bond with another sulfonate anion located in the $\mathrm{i}-2$ sheet. The $\mathrm{C}_{\mathrm{sp}^{-}}$ $\mathrm{H} \cdots \mathrm{O}$ (sulfonate) hydrogen bond length is $2.35 \AA$ and the $\mathrm{C}_{\mathrm{sp}} \cdots \mathrm{O}$ distance $3.241(2) \AA$. The $\mathrm{C}_{\mathrm{sp}}-\mathrm{H} \cdots \mathrm{O}$ angle is $156.3^{\circ}$. These geometrical parameters compare well with the values found in the literature: a CSD analysis indicates that the mean $\mathrm{C}_{\mathrm{sp}}-\mathrm{H} \cdots \mathrm{O}$ distance is 2.40(2) $\AA$ and the mean $\mathrm{C}_{\mathrm{sp}} \cdots \mathrm{O}$ distance $3.35(1) \AA{ }^{[49]} \mathrm{C}_{\mathrm{sp}}-\mathrm{H} \cdots \mathrm{O}$ angles cluster in the range $150-160^{\circ} .{ }^{[50,51]}$ It is noteworthy that $\mathrm{C} \equiv \mathrm{C}-\mathrm{H} \cdots \mathrm{C} \equiv \mathrm{C}$ interactions as those observed in simple alkynes are not present. ${ }^{[52]}$ Evidently, the structure of $\mathbf{5}$ is governed by the guanidinium sulfonate sheet motif. 
Figure 6, here 


\section{Conclusion}

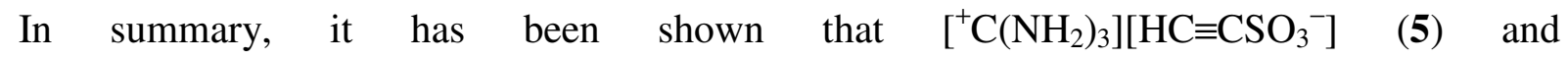
$\left[{ }^{+} \mathrm{C}\left(\mathrm{NH}_{2}\right)_{3}\right]\left[\mathrm{CH}_{3} \mathrm{C} \equiv \mathrm{CSO}_{3}{ }^{-}\right]$(6) both crystallize with a single layer structure. Hence, the hydrogen bonded sheet motif observed previously in guanidinium alkane- and arenesulfonates is maintained when the organosulfonate $\mathrm{R}$ group is changed for an alkyne group. As found in other guanidinium sulfonate salts, the robust $\mathrm{N}-\mathrm{H} \cdots \mathrm{O}$ (sulfonate) hydrogen bond network controls the packing of the molecules. Interactions such as $\mathrm{N}-\mathrm{H} \cdots \mathrm{C} \equiv \mathrm{C}$ and $\mathrm{C}_{\mathrm{sp}}-\mathrm{H} \cdots \mathrm{O}$ are too weak to disrupt this network, unlike the situation observed in systems possessing substituents with strong hydrogen bonding capabilities. ${ }^{[10,13]}$ Yet, it was found that these weak interactions were capable of bringing subtle changes to the basic arrangement: in the case of $\mathbf{6}$, a compact structure is obtained in which the sheets are highly interdigitated due to the presence of numerous $\mathrm{N}-\mathrm{H} \cdots \mathrm{C} \equiv \mathrm{C}$ contacts. In the case of $\mathbf{5}$, the hydrogen bonded sheets all have ethynyl moieties pointing in the same direction because of interlayer $\mathrm{C}_{\mathrm{sp}}-\mathrm{H} \cdots \mathrm{O}$ interactions between organosulfonate anions. On the basis of Desiraju's classification, the latter hydrogen bond may be regarded as intrusive. ${ }^{[5]}$ In effect, the structure of $\mathbf{5}$ is reminiscent of some work published by Janiak in which an "inverse bilayer" structure was observed for a series of 1,1'binaphthalene-2,2'-diyl phosphate salts. ${ }^{[53]}$ This unusual situation was ascribed to hydrogen bonding from the cations and solvent molecules to the hydrophilic $(\mathrm{RO})_{2} \mathrm{PO}_{2}{ }^{-}$phosphate heads which creates an interior hydrophilic region and exposes the binaphthyl groups on both exterior sides. The present study is currently being extended to guanidinium disulfonates bearing alkyne and diacetylenic groups to see how these salts compare with guanidinium $\alpha, \omega-$ alkane- and arenedisulfonates. Also, work is underway to see if other weak interactions such as arene...perfluoroarene have structure-modifying abilities similar to those of the N$\mathrm{H} \cdots \mathrm{C} \equiv \mathrm{C}$ and $\mathrm{C}_{\mathrm{sp}}-\mathrm{H} \cdots \mathrm{O}$ (sulfonate) interactions reported here. 


\section{Experimental Section}

General considerations: Solution ${ }^{1} \mathrm{H}$ and ${ }^{29} \mathrm{Si}$ NMR spectra were recorded on a Bruker Avance DPX 200 spectrometer. ${ }^{13} \mathrm{C}$ NMR spectra were obtained on either one of the following Bruker instruments: Avance DPX 200, AC 250, Avance DRX 400. ${ }^{1} \mathrm{H}$ chemical shifts were referenced to the protio impurity of the NMR solvent, ${ }^{13} \mathrm{C}$ chemical shifts to the NMR solvent, and ${ }^{29} \mathrm{Si}$ NMR chemical shifts to tetramethylsilane. Infrared spectra were recorded on a Thermo Nicolet Avatar 320 FT-IR spectrometer with a $4 \mathrm{~cm}^{-1}$ resolution. Melting points were measured on a Büchi B-540 melting point apparatus and are uncorrected. FAB mass spectra were obtained on JEOL JMS-SX102A and JEOL JMS-DX300 instruments. HRMS measurements were performed on a Varian MAT 311 double focusing mass spectrometer at the Centre Régional de Mesures Physiques de l'Ouest (CRMPO), Université de Rennes I, Rennes, France, using electron impact $(70 \mathrm{eV})$ as ionization mode. Elemental analyses were carried out at the Service Central de Microanalyse of the Centre National de la Recherche Scientifique (CNRS), Vernaison, France.

Materials: (Trimethylsilyl)acetylene (98\%) was purchased from Lancaster and 1trimethylsilyl-1-propyne (97\%) from Alfa Aesar. Guanidinium carbonate (99\%) was obtained from Aldrich and used as supplied. 1,4-Dioxane (extra dry, with molecular sieves, water $<50$ ppm, stabilized) and water (for HPLC gradient grade) were purchased from Acrōs Organics. Dichloromethane was distilled over $\mathrm{CaH}_{2}$ prior to use. $\mathrm{ClSO}_{3} \mathrm{SiMe}_{3}$ and $\mathrm{SO}_{3}$.dioxane were prepared as described in the literature. ${ }^{[46]}$

Synthesis of $\mathbf{H C} \equiv \mathrm{CSO}_{3} \mathrm{SiMe}_{3}$ (1): Alkyne 1 was synthesized by sulfonation of $\mathrm{HC} \equiv \mathrm{CSiMe}_{3}$ with $\mathrm{ClSO}_{3} \mathrm{SiMe}_{3}$ as described by Mérault. ${ }^{[46]}$

Synthesis of $\mathrm{CH}_{3} \mathrm{C} \equiv \mathrm{CSO}_{3} \mathrm{SiMe}_{3}$ (2): Alkyne 2 was synthesized by sulfonation of $\mathrm{CH}_{3} \mathrm{C} \equiv \mathrm{CSiMe}_{3}$ with $\mathrm{SO}_{3}$.dioxane following a procedure adapted from Mérault. ${ }^{[46]}$ After completion of the reaction, the volatiles were removed and the crude product was purified by vacuum distillation $\left(50{ }^{\circ} \mathrm{C}, 0.05\right.$ mbar). A colorless viscous liquid was obtained; yield: $80 \%$. ${ }^{1} \mathrm{H}$ NMR (200.1 MHz, $\left.\mathrm{CDCl}_{3}\right): \delta=0.49$ (s, 9H; $\left.\mathrm{Si}\left(\mathrm{CH}_{3}\right)_{3}\right), 2.10 \mathrm{ppm}\left(\mathrm{s}, 3 \mathrm{H} ; \mathrm{CH}_{3} \mathrm{C} \equiv\right) ;{ }^{13} \mathrm{C}$ NMR (100.6 MHz, $\left.\mathrm{CDCl}_{3}\right): \delta=-0.2\left(\mathrm{Si}\left(\mathrm{CH}_{3}\right)_{3}\right), 3.3\left(\mathrm{CH}_{3}\right), 74.5\left(\mathrm{CSO}_{3}\right), 88.3 \mathrm{ppm}$ $\left(\mathrm{CH}_{3} \mathrm{C} \equiv\right) ;{ }^{29} \mathrm{Si} \mathrm{NMR}\left(39.8 \mathrm{MHz}, \mathrm{CDCl}_{3}\right): \delta=35.8 \mathrm{ppm}\left(\mathrm{Si}\left(\mathrm{CH}_{3}\right)_{3}\right) ; \mathrm{IR}\left(\mathrm{CCl}_{4}\right): \tilde{v}=2960(\mathrm{w}$;

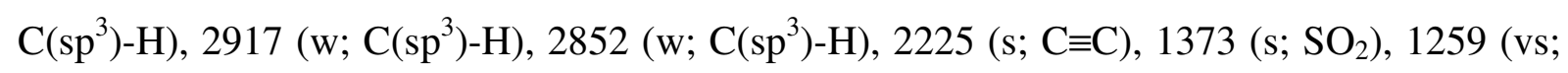
$\mathrm{Si}-\mathrm{CH}_{3}$ ), $1187 \mathrm{~cm}^{-1}$ (vs; $\mathrm{SO}_{2}$ ); $\operatorname{HRMS}(\mathrm{EI}): \mathrm{m} / z$ calcd for $\mathrm{C}_{5} \mathrm{H}_{9} \mathrm{O}_{3} \mathrm{SSi}^{+}\left[M-\mathrm{CH}_{3}\right]^{+}$: 
177.00417; found: 177.0045; elemental analysis calcd (\%) for $\mathrm{C}_{6} \mathrm{H}_{12} \mathrm{O}_{3} \mathrm{SSi}$ (192.3045): C 37.47, H 6.29, S 16.67; found: C 35.30, H 5.74, S 17.6.

Synthesis of $\mathbf{H C} \equiv \mathrm{CSO}_{3} \mathbf{H} \cdot \mathbf{2 . 3 3} \mathbf{H}_{2} \mathrm{O}(3)$ : A 7-mL portion of deionized water was added to a diethyl ether solution $(10 \mathrm{~mL})$ containing $1(12.5 \mathrm{~g}, 70 \mathrm{mmol})$. The two-phase mixture was stirred overnight. The two layers were separated and the aqueous layer was washed three times with diethyl ether to remove completely the hexamethyldisiloxane formed in the reaction. The aqueous layer was concentrated on a rotary evaporator, then heated to $79{ }^{\circ} \mathrm{C}$ on a vacuum-line. The residual liquid was left to stand at room temperature during which time a solid formed. ${ }^{1} \mathrm{H}$ NMR spectroscopy and elemental analysis showed the amount of water per mole of sulfonic acid to be 2.33 , which is close to the $\mathrm{HC} \equiv \mathrm{CSO}_{3} \mathrm{H} \cdot 2.5 \mathrm{H}_{2} \mathrm{O}$ composition reported by Mérault; ${ }^{[46]}$ yield: $74 \%$. The solid is hygroscopic and turns into a liquid on exposure to air over a period of several days. ${ }^{1} \mathrm{H}$ NMR (200.1 MHz, [D 6 DMSO): $\delta=3.60$ (s, $1 \mathrm{H} ; \mathrm{HC} \equiv), 7.64 \mathrm{ppm}\left(\mathrm{s}, 5.66 \mathrm{H} ; \mathrm{SO}_{3} \mathrm{H}+\mathrm{H}_{2} \mathrm{O}\right) ;{ }^{13} \mathrm{C} \mathrm{NMR}\left(62.9 \mathrm{MHz},\left[\mathrm{D}_{6}\right] \mathrm{DMSO}\right): \delta=69.8$

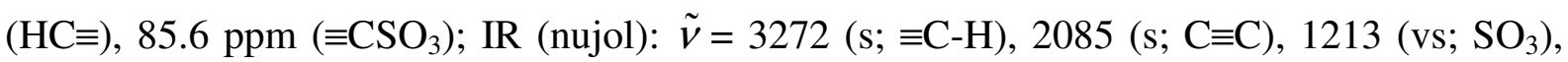
$1055 \mathrm{~cm}^{-1}$ (s; $\mathrm{SO}_{3}$ ); HRMS (EI): $\mathrm{m} / z$ calcd for $\mathrm{C}_{2} \mathrm{H}_{2} \mathrm{O}_{3} \mathrm{~S}^{+}[M]^{+}:$105.97247; found: 105.9722; elemental analysis calcd (\%) for $\mathrm{C}_{2} \mathrm{H}_{2} \mathrm{O}_{3} \mathrm{~S} \cdot 2.33 \mathrm{H}_{2} \mathrm{O}$ (148.0714): C 16.22, H 4.53, O 57.59, S 21.65; found: C 16.70, H 4.25, O 57.29, S 21.98.

Synthesis of $\mathbf{C H}_{3} \mathbf{C} \equiv \mathrm{CSO}_{3} \mathbf{H} \cdot 1.88 \mathbf{H}_{2} \mathrm{O}$ (4): An Erlenmeyer flask containing 2 (2.91 g, 15.1 mmol) was left open in a freezer at $-10{ }^{\circ} \mathrm{C}$ over a period of three days. The hydrolyzed material was allowed to come to room temperature, then a $20-\mathrm{mL}$ portion of deionized water was added. The aqueous layer was washed with three $20-\mathrm{mL}$ portions of diethyl ether to remove completely the hexamethyldisiloxane formed in the reaction. The aqueous layer was concentrated on a rotary evaporator. A brown viscous liquid was obtained for which ${ }^{1} \mathrm{H}$ NMR spectroscopy and elemental analysis established that the composition was $\mathrm{CH}_{3} \mathrm{C} \equiv \mathrm{CSO}_{3} \mathrm{H} \cdot 1.88$ $\mathrm{H}_{2} \mathrm{O}$; yield: $96 \% .{ }^{1} \mathrm{H}$ NMR (200.1 MHz, $\mathrm{CDCl}_{3}$ ): $\delta=2.12$ (s, 3H; $\mathrm{CH}_{3}$ ), 9.91 ppm (s, 4.76H; $\left.\mathrm{SO}_{3} \mathrm{H}+\mathrm{H}_{2} \mathrm{O}\right) ;{ }^{13} \mathrm{C}$ NMR $\left(50.3 \mathrm{MHz}, \mathrm{CDCl}_{3}\right): \delta=3.3\left(\mathrm{CH}_{3}\right), 79.8\left(\mathrm{CH}_{3} C \equiv\right), 81.2 \mathrm{ppm}$ $\left(\equiv \mathrm{CSO}_{3}\right) ; \mathrm{IR}$ (neat): $\tilde{v}=2926\left(\mathrm{w} ; \mathrm{C}\left(\mathrm{sp}^{3}\right)-\mathrm{H}\right), 2222$ (vs; $\left.\mathrm{C} \equiv \mathrm{C}\right), 1132$ (vs; $\left.\mathrm{SO}_{3}\right), 1057 \mathrm{~cm}^{-1}$ (vs; $\left.\mathrm{SO}_{3}\right)$; FAB- MS (GT): $\mathrm{m} / z(\%): 119$ (39) $\left[\mathrm{CH}_{3} \mathrm{C} \equiv \mathrm{CSO}_{3}{ }^{-}\right]$; elemental analysis calcd (\%) for $\mathrm{C}_{3} \mathrm{H}_{4} \mathrm{O}_{3} \mathrm{~S} \cdot 1.88 \mathrm{H}_{2} \mathrm{O}$ (153.991): C 23.40, H 5.08, S 20.82; found: C 23.22, H 5.39, S 20.97.

Synthesis of $\left[{ }^{+} \mathbf{C}\left(\mathrm{NH}_{2}\right)_{3}\right]\left[\mathbf{H C} \equiv \mathbf{C S O}_{3}{ }^{-}\right](5)$ : Guanidinium ethynesulfonate (5) was synthesized by dissolving and stirring in water stoichiometric amounts of sulfonic acid $\mathbf{3}$ and guanidinium carbonate. A dark powder was obtained upon removal of the solvent. The crude product was decolorized with activated charcoal and recrystallized from an ethanol-diethyl ether mixture 
to give a pale yellow powder; yield $=79 \%$. M.p. $113.6-129.7{ }^{\circ} \mathrm{C} ;{ }^{1} \mathrm{H}$ NMR $(200.1 \mathrm{MHz}$, $\left.\left[\mathrm{D}_{6}\right] \mathrm{DMSO}\right): \delta=3.66(\mathrm{~s}, 1 \mathrm{H} ; \mathrm{HC} \equiv), 6.88 \mathrm{ppm}\left(\mathrm{s}, 6 \mathrm{H} ;{ }^{+} \mathrm{C}\left(\mathrm{NH}_{2}\right)_{3}\right) ;{ }^{13} \mathrm{C} \mathrm{NMR}(62.9 \mathrm{MHz}$, [D 6 DMSO): $\delta=69.6(\mathrm{HC} \equiv), 85.9\left(\equiv \mathrm{CSO}_{3}\right), 157.7 \mathrm{ppm}\left({ }^{+} \mathrm{C}\left(\mathrm{NH}_{2}\right)_{3}\right) ; \mathrm{IR}(\mathrm{KBr}): \tilde{v}=3404(\mathrm{br}$;

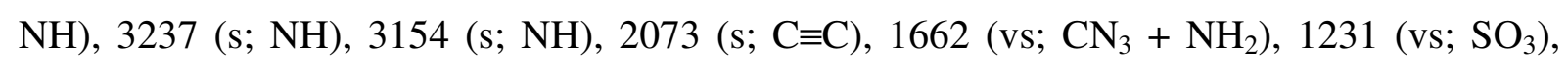

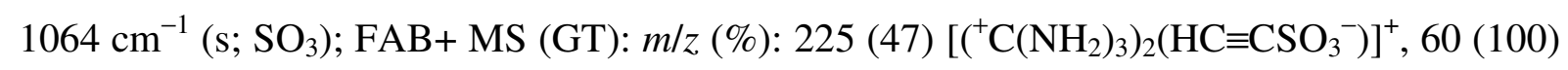
$\left[{ }^{+} \mathrm{C}\left(\mathrm{NH}_{2}\right)_{3}\right] ; \mathrm{FAB}-\mathrm{MS}$ (GT): m/z (\%): $270(17)\left[\left({ }^{+} \mathrm{C}\left(\mathrm{NH}_{2}\right)_{3}\right)\left(\mathrm{HC} \equiv \mathrm{CSO}_{3}{ }^{-}\right)_{2}\right]^{-}, 105$ (100) $\left[\mathrm{HC} \equiv \mathrm{CSO}_{3}{ }^{-}\right]$; elemental analysis calcd $(\%)$ for $\mathrm{C}_{3} \mathrm{H}_{7} \mathrm{~N}_{3} \mathrm{O}_{3} \mathrm{~S}$ (165.1666): $\mathrm{C} 21.82, \mathrm{H} \mathrm{4.27,} \mathrm{N}$ 25.44, O 29.06, S 19.41; found: C 21.23, H 4.08, N 22.06, O 30.47, S 19.13.

Synthesis of $\left[{ }^{+} \mathbf{C}\left(\mathrm{NH}_{2}\right)_{3}\right]\left[\mathrm{CH}_{3} \mathrm{C} \equiv \mathrm{CSO}_{3}{ }^{-}\right](6)$ : Sulfonic acid 4 was reacted with guanidinium carbonate following the same procedure as that used to prepare $\mathbf{5}$ (see above). Recrystallization of the crude product from an ethanol-diethyl ether mixture gave a white powder; yield $=85 \%$. M.p. $138-182{ }^{\circ} \mathrm{C} ;{ }^{1} \mathrm{H}$ NMR $\left(200.1 \mathrm{MHz},\left[\mathrm{D}_{6}\right] \mathrm{DMSO}\right): \delta=1.84(\mathrm{~s}, 3 \mathrm{H}$; $\left.\mathrm{CH}_{3}\right), 6.98 \mathrm{ppm}\left(\mathrm{s}, 6 \mathrm{H} ;{ }^{+} \mathrm{C}\left(\mathrm{NH}_{2}\right)_{3}\right) ;{ }^{13} \mathrm{C} \mathrm{NMR}\left(50.3 \mathrm{MHz},\left[\mathrm{D}_{6}\right] \mathrm{DMSO}\right): \delta=3.5\left(\mathrm{CH}_{3}\right), 78.4$ $\left(\mathrm{CH}_{3} \mathrm{C} \equiv\right), 82.6\left(\equiv \mathrm{CSO}_{3}\right), 158.7 \mathrm{ppm}\left({ }^{+} \mathrm{C}\left(\mathrm{NH}_{2}\right)_{3}\right) ; \mathrm{IR}(\mathrm{KBr}): \tilde{v}=3419(\mathrm{br} ; \mathrm{NH}), 3271(\mathrm{~s} ; \mathrm{NH})$, 3201 (s; NH), 2223 (s; C $\equiv \mathrm{C}$ ), 1659 (vs; $\mathrm{CN}_{3}+\mathrm{NH}_{2}$ ), 1229 (vs; $\mathrm{SO}_{3}$ ), $1065 \mathrm{~cm}^{-1}$ (s; $\mathrm{SO}_{3}$ ); $\mathrm{FAB}+\mathrm{MS}$ (GT): $m / z(\%): 239$ (34) $\left[\left({ }^{+} \mathrm{C}\left(\mathrm{NH}_{2}\right)_{3}\right)_{2}\left(\mathrm{CH}_{3} \mathrm{C} \equiv \mathrm{CSO}_{3}{ }^{-}\right)\right]^{+}, 60$ (100) $\left[{ }^{+} \mathrm{C}\left(\mathrm{NH}_{2}\right)_{3}\right]$; FAB- MS (GT): $m / z(\%): 298(46)\left[\left({ }^{+} \mathrm{C}\left(\mathrm{NH}_{2}\right)_{3}\right)\left(\mathrm{CH}_{3} \mathrm{C} \equiv \mathrm{CSO}_{3}{ }^{-}\right)_{2}\right]^{-}, 119$ (100) $\left[\mathrm{CH}_{3} \mathrm{C} \equiv \mathrm{CSO}_{3}{ }^{-}\right]$; elemental analysis calcd (\%) for $\mathrm{C}_{4} \mathrm{H}_{9} \mathrm{~N}_{3} \mathrm{O}_{3} \mathrm{~S}$ (179.1934): C 26.81, H 5.06, N 23.45, O 26.79, S 17.89; found: C 26.14, H 5.37, N 22.93, O 26.75, S 18.20.

X-ray diffraction: Single-crystals of $\mathbf{5}$ and $\mathbf{6}$ were grown from water. X-ray diffraction experiments were carried out on a Stoe Imaging Plate Diffraction System (IPDS) equipped with an Oxford Cryosystems Cryostream Cooler Device. Intensity data were collected at 180 $\mathrm{K}$ in both cases. The crystal-to-detector distance was $70 \mathrm{~mm}$ for both measurements. For $\mathbf{5}$, a total of 179 exposures ( 4 min per exposure) were taken with $0<\varphi<250.6^{\circ}$ and crystal oscillations of $1.4^{\mathrm{o}}$ in $\varphi^{[54]}$ For $\mathbf{6}, 139$ exposures (5 min per exposure) were taken with $0<\varphi$ $<250.2^{\circ}$ and crystal oscillations of $1.8^{\circ}$ in $\varphi$. No decay corrections were made to the data based on intensity checks of two hundred control reflections. The cell parameters were refined from 8000 reflections. Owing to the low values of $\mu$, no absorption corrections were made.

Both structures were solved by direct methods (SHELXS-97). ${ }^{[55]}$ The SHELXL-97 program was used for full-matrix least-squares refinement against $F_{\mathrm{o}}{ }^{2}$ using all reflections. ${ }^{[56]}$ Atomic scattering factors were taken from a standard source. ${ }^{[57]}$ All non-hydrogen atoms were refined anisotropically. Hydrogen atoms were introduced in the calculations with the riding model, 
with isotropic thermal parameters equal to 1.1 times that of the atom of attachment. Final $R$ values and relevant crystallographic data are given in Table 1.

CCDC-735562 (5) and CCDC-735561 (6) contain the supplementary crystallographic data for this paper. These data can be obtained free of charge via www.ccdc.cam.ac.uk/conts/retrieving.html (or from the Cambridge Crystallographic Data Centre, 12 Union Road, Cambridge CB2 1EZ, UK; fax: (+44) 1223-336-033; or e-mail: deposit@ccdc.cam.ac.uk). 


\section{Acknowledgment}

We are indebted to Dr. Pierre Guenot from the Centre Régional de Mesures Physiques de l'Ouest (CRMPO), Université de Rennes I, Rennes, France, for obtaining the HRMS results reported in this work. We also thank Dr. Arie van der Lee from the Institut Européen des Membranes (UMR 5635, Université Montpellier II, Montpellier, France) for helpful discussions concerning the X-ray crystal structures of sulfonates 5 and $\mathbf{6}$. 


\section{References}

[1] G. A. Jeffrey, An Introduction to Hydrogen Bonding, Oxford University Press, New York, 1997.

[2] J. P. Glusker in Design of Organic Solids; Topics in Current Chemistry 198 (Ed.: E. Weber), Springer-Verlag, Berlin, 1998, p. 1.

[3] G. A. Jeffrey, W. Saenger, Hydrogen Bonding in Biological Structures, Springer, Berlin, 1991.

[4] G. R. Desiraju, T. Steiner, The Weak Hydrogen Bond in Structural Chemistry and Biology; IUCr Monographs on Crystallography 9, Oxford University Press, Oxford, 1999.

[5] G. R. Desiraju, Chem. Commun. 2005, 2995-3001.

[6] G. R. Desiraju, Crystal Engineering: The Design of Organic Solids; Materials Science Monographs 54, Elsevier, Amsterdam, 1989.

[7] G. R. Desiraju in Solid-state Supramolecular Chemistry: Crystal Engineering; Comprehensive Supramolecular Chemistry, Vol. 6 (Eds.: D. D. MacNicol, F. Toda, R. Bishop), Elsevier, Oxford, 1996, p. 1.

[8] A. Nangia, G. R. Desiraju in Design of Organic Solids; Topics in Current Chemistry 198 (Ed.: E. Weber), Springer-Verlag, Berlin, 1998, p. 57.

[9] V. A. Russell, M. C. Etter, M. D. Ward, J. Am. Chem. Soc. 1994, 116, 1941-1952.

[10] V. A. Russell, M. C. Etter, M. D. Ward, Chem. Mater. 1994, 6, 1206-1217.

[11] V. A. Russell, M. D. Ward, Acta Crystallogr., Sect. B 1996, 52, 209-214.

[12] V. A. Russell, M. D. Ward, Chem. Mater. 1996, 8, 1654-1666.

[13] V. A. Russell, M. D. Ward, J. Mater. Chem. 1997, 7, 1123-1133.

[14] M. J. Horner, K. T. Holman, M. D. Ward, Angew. Chem. 2001, 113, 4169-4172; Angew. Chem. Int. Ed. 2001, 40, 4045-4048.

[15] D. A. Haynes, J. A. Chisholm, W. Jones, W. D. S. Motherwell, CrystEngComm 2004, $6,584-588$.

[16] M. D. Ward, Chem. Commun. 2005, 5838-5842.

[17] N. J. Burke, A. D. Burrows, M. F. Mahon, S. J. Teat, CrystEngComm 2004, 6, 429436.

[18] N. J. Burke, A. D. Burrows, M. F. Mahon, J. E. Warren, Cryst. Growth Des. 2006, 6, 546-554.

[19] M. J. Horner, K. T. Holman, M. D. Ward, J. Am. Chem. Soc. 2007, 129, 14640-14660. 
[20] Graph notation was originally proposed by Etter. See: a) M. C. Etter, Acc. Chem. Res. 1990, 23, 120-126; b) M. C. Etter, J. C. MacDonald, J. Bernstein, Acta Crystallogr., Sect. B 1990, 46, 256-262; c) M. C. Etter, J. Phys. Chem. 1991, 95, 4601-4610.

[21] F. Mathevet, P. Masson, J.-F. Nicoud, A. Skoulios, Chem. Eur. J. 2002, 8, 2248-2254.

[22] S. M. Martin, J. Yonezawa, M. J. Horner, C. W. Macosko, M. D. Ward, Chem. Mater. 2004, 16, 3045-3055.

[23] S. M. Martin, M. D. Ward, Langmuir 2005, 21, 5324-5331.

[24] F. Mathevet, P. Masson, J.-F. Nicoud, A. Skoulios, J. Am. Chem. Soc. 2005, 127, 9053-9061.

[25] J. A. Swift, V. A. Russell, M. D. Ward, Adv. Mater. 1997, 9, 1183-1186.

[26] V. A. Russell, C. C. Evans, W. Li, M. D. Ward, Science (Washington, D. C.) 1997, $276,575-579$.

[27] J. A. Swift, A. M. Pivovar, A. M. Reynolds, M. D. Ward, J. Am. Chem. Soc. 1998, $120,5887-5894$.

[28] J. A. Swift, A. M. Reynolds, M. D. Ward, Chem. Mater. 1998, 10, 4159-4168.

[29] C. C. Evans, L. Sukarto, M. D. Ward, J. Am. Chem. Soc. 1999, 121, 320-325.

[30] K. T. Holman, M. D. Ward, Angew. Chem. 2000, 112, 1719-1722; Angew. Chem. Int. Ed. 2000, 39, 1653-1656.

[31] J. A. Swift, M. D. Ward, Chem. Mater. 2000, 12, 1501-1504.

[32] K. T. Holman, A. M. Pivovar, J. A. Swift, M. D. Ward, Acc. Chem. Res. 2001, 34, 107-118.

[33] K. T. Holman, S. M. Martin, D. P. Parker, M. D. Ward, J. Am. Chem. Soc. 2001, 123, 4421-4431.

[34] A. M. Pivovar, K. T. Holman, M. D. Ward, Chem. Mater. 2001, 13, 3018-3031.

[35] K. T. Holman, A. M. Pivovar, M. D. Ward, Science (Washington, D. C.) 2001, 294, 1907-1911.

[36] Y. Aoyama in Design of Organic Solids; Topics in Current Chemistry 198 (Ed.: E. Weber), Springer-Verlag, Berlin, 1998, p. 131.

[37] R. Custelcean, M. D. Ward, Cryst. Growth Des. 2005, 5, 2277-2287.

[38] J. N. Voogt, H. W. Blanch, Cryst. Growth Des. 2005, 5, 1135-1144.

[39] J. Xie, M. T. Ma, B. F. Abrahams, A. G. Wedd, Inorg. Chem. 2007, 46, 9027-9029.

[40] F. Carré, S. G. Dutremez, C. Guérin, B. J. L. Henner, A. Jolivet, V. Tomberli, F. Dahan, Organometallics 1999, 18, 770-781. 
[41] S. G. Dutremez, C. Guérin, B. J. L. Henner, V. Tomberli, Phosphorus, Sulfur and Silicon 2000, 160, 251-269.

[42] L. Brunel, G. Chaplais, S. G. Dutremez, C. Guérin, B. J. L. Henner, V. Tomberli, Organometallics 2000, 19, 2516-2525.

[43] L. Brunel, F. Carré, S. G. Dutremez, C. Guérin, F. Dahan, O. Eisenstein, G. Sini, Organometallics 2001, 20, 47-54.

[44] F. Carré, N. Devylder, S. G. Dutremez, C. Guérin, B. J. L. Henner, A. Jolivet, V. Tomberli, F. Dahan, Organometallics 2003, 22, 2014-2033.

[45] Permanently porous networks sustained by charge-assisted hydrogen bonding between alkynesulfonates and $\mathrm{Ni}(\text { tame })_{2}{ }^{2+}$ (tame $=1,1,1$-tris(aminomethyl)ethane) have been described. See: S. A. Dalrymple, G. K. H. Shimizu, J. Am. Chem. Soc. 2007, 129, 12114-12116.

[46] G. Mérault, Thèse de doctorat d'état ès Sciences Physiques, Université de Bordeaux I, France, 1974.

[47] R. Calas, P. Bourgeois, C. R. Acad. Sci., Paris, Sér. C 1969, 268, 1525-1527.

[48] M. Pilkington, J. D. Wallis, G. T. Smith, J. A. K. Howard, J. Chem. Soc., Perkin Trans. 2 1996, 1849-1854.

[49] T. Steiner, New J. Chem. 1998, 22, 1099-1103.

[50] G. R. Desiraju, Acc. Chem. Res. 1991, 24, 290-296.

[51] T. Steiner, Chem. Commun. 1997, 727-734.

[52] a) T. Steiner, J. Chem. Soc., Chem. Commun. 1995, 95-96; b) T. Steiner, E. B. Starikov, A. M. Amado, J. J. C. Teixeira-Dias, J. Chem. Soc., Perkin Trans. 2 1995, 1321-1326; c) H.-C. Weiss, D. Bläser, R. Boese, B. M. Doughan, M. M. Haley, Chem. Commun. 1997, 1703-1704; d) H.-C. Weiss, R. Boese, H. L. Smith, M. M. Haley, Chem. Commun. 1997, 2403-2404; e) J. M. A. Robinson, B. M. Kariuki, R. J. Gough, K. D. M. Harris, D. Philp, J. Solid State Chem. 1997, 134, 203-206; f) E. Galoppini, R. Gilardi, Chem. Commun. 1999, 173-174.

[53] T. Dorn, A.-C. Chamayou, C. Janiak, New J. Chem. 2006, 30, 156-167.

[54] Stoe IPDS Manual: Version 2.93, Stoe \& Cie, Darmstadt, Germany, 1997.

[55] G. M. Sheldrick, SHELXS-97, Program for Crystal Structure Solution, University of Göttingen, Göttingen, Germany, 1990.

[56] G. M. Sheldrick, SHELXL-97, Program for the Refinement of Crystal Structures from Diffraction Data, University of Göttingen, Göttingen, Germany, 1997. 
[57] International Tables for Crystallography, Kluwer Academic Publishers, Dordrecht, The Netherlands, 1992, Vol. C, Tables 4.2.6.8 and 6.1.1.4. 


\section{Legends}

Scheme 1. Schematic representation showing the arrangement of the guanidinium sulfonate motif as a function of increasing dimension.

Scheme 2. Syntheses of compounds $\mathbf{1}$ and 2.

Scheme 3. Syntheses of compounds 3-6.

Figure 1. View along the $a$-axis showing the hydrogen bond network in $\mathbf{6}$. Ions connected through dotted lines belong to the main layer (i sheet). Rows of sulfonate anions labelled $\underline{\mathbf{A}}$ and $\underline{\mathbf{C}}$ belong to the $\mathrm{i}+1$ sheet. Rows of sulfonate anions labelled $\underline{\mathbf{B}}$ and $\underline{\mathbf{D}}$ belong to the $\mathrm{i}-1$ sheet.

Figure 2. View along the $b$-axis depicting the single layer structure of $\mathbf{6}$. Three layers are shown that are labelled $\mathrm{i}, \mathrm{i}-1$, and $\mathrm{i}+1$. Rows of sulfonate anions marked $\underline{\mathbf{A}}, \underline{\mathbf{B}}$, $\underline{\mathbf{C}}$, and $\underline{\mathbf{D}}$ are the same as in Figure 1 .

Figure 3. View along the $c$-axis showing the hydrogen bond network in $\mathbf{5}$.

Figure 4. View perpendicular to the $c$-axis showing the stacking of the layers in $\mathbf{5}$.

Figure 5. View showing N-H $\cdots \pi$ interactions (dashed lines) in crystalline 6.

Figure 6. View perpendicular to the $c$-axis showing $\mathrm{C}_{\mathrm{sp}}-\mathrm{H} \cdots \mathrm{O}$ contacts (dashed lines) between sulfonate anions from the $\mathrm{i}$ and $\mathrm{i}-2$ layers in crystalline $\mathbf{5}$. 
Table 1. Crystal Data and Experimental Details of Data Collection and Refinement for $\mathbf{5}$ and 6.

\begin{tabular}{|c|c|c|}
\hline Compound & 5 & 6 \\
\hline empirical formula & $\mathrm{C}_{3} \mathrm{H}_{7} \mathrm{~N}_{3} \mathrm{O}_{3} \mathrm{~S}$ & $\mathrm{C}_{4} \mathrm{H}_{9} \mathrm{~N}_{3} \mathrm{O}_{3} \mathrm{~S}$ \\
\hline formula weight & 165.18 & 179.20 \\
\hline crystal color & colorless & colorless \\
\hline crystal size $[\mathrm{mm}]$ & $0.45 \times 0.30 \times 0.25$ & $0.50 \times 0.45 \times 0.20$ \\
\hline crystal system & hexagonal & orthorhombic \\
\hline space group & $P 6_{3}$ (No. 173) & Pnma (No. 62) \\
\hline$a[\AA]$ & $13.4466(11)$ & $7.9199(8)$ \\
\hline$b[\AA]$ & $13.4466(11)$ & $23.304(2)$ \\
\hline$c[\AA]$ & $6.6927(5)$ & $13.1285(14)$ \\
\hline$\alpha\left[^{\circ}\right]$ & 90 & 90 \\
\hline$\beta\left[^{\circ}\right]$ & 90 & 90 \\
\hline$\gamma\left[^{\circ}\right]$ & 120 & 90 \\
\hline$V\left[\AA^{3}\right]$ & $1047.99(14)$ & $2423.0(4)$ \\
\hline$Z$ & 6 & 12 \\
\hline$\rho_{\text {calcd }}\left[\mathrm{g} \mathrm{cm}^{-3}\right]$ & 1.570 & 1.474 \\
\hline$F(000)$ & 516 & 1128 \\
\hline$\mu\left[\mathrm{mm}^{-1}\right]$ & 0.416 & 0.366 \\
\hline$T[\mathrm{~K}]$ & 180 & 180 \\
\hline $\begin{array}{l}\text { graphite-monochromated Mo } \mathrm{K} \alpha \\
\text { radiation }[\AA]\end{array}$ & 0.71073 & 0.71073 \\
\hline $2 \theta$ range $\left[{ }^{\circ}\right]$ & $3.3-52.1$ & $3.3-52.1$ \\
\hline index ranges & $\begin{array}{l}-16 \leq h \leq 16,-16 \leq k \leq 16, \\
-7 \leq l \leq 7\end{array}$ & $\begin{array}{l}-9 \leq h \leq 9,-28 \leq k \leq 28, \\
-16 \leq l \leq 16\end{array}$ \\
\hline reflections collected & 10375 & 21777 \\
\hline independent reflections & 1309 & 2435 \\
\hline$R_{\text {int }}($ on I $)$ & 0.0258 & 0.0252 \\
\hline no. of obsd reflns $\left(F_{\mathrm{o}}>4 \sigma\left(F_{\mathrm{o}}\right)\right)$ & 1226 & 2240 \\
\hline parameters refined & 91 & 160 \\
\hline goodness-of-fit on $F_{\mathrm{o}}^{2}$ (all reflns) & 1.064 & 1.198 \\
\hline $\mathrm{w}^{[\mathrm{a}]}$ & {$\left[\sigma^{2}\left(F_{\mathrm{o}}^{2}\right)+(0.0283 \mathrm{P})^{2}\right]^{-1}$} & {$\left[\sigma^{2}\left(F_{\mathrm{o}}^{2}\right)+0.2076 \mathrm{P}\right]^{-1}$} \\
\hline max and mean shift/esd & $0.000,0.000$ & $0.001,0.000$ \\
\hline$R^{[\mathrm{b}]} R_{\mathrm{W}}^{[\mathrm{c}]}$ (obsd reflns) & $0.0200,0.0425$ & $0.0180,0.0358$ \\
\hline$R,{ }^{[\mathrm{b}]} R_{\mathrm{w}}^{[\mathrm{c}]}$ (all reflns) & $0.0205,0.0425$ & $0.0190,0.0360$ \\
\hline largest diff. peak and hole [e $\AA^{-3}$ ] & $0.127,-0.123$ & $0.159,-0.160$ \\
\hline
\end{tabular}

[a] $\mathrm{P}=\left(F_{\mathrm{o}}^{2}+2 F_{\mathrm{c}}^{2}\right) / 3$. [b] $R=\Sigma\left\|F_{\mathrm{o}}|-| F_{\mathrm{c}}\right\| / \Sigma\left|F_{\mathrm{o}}\right| .[\mathrm{c}] R_{\mathrm{w}}=\left[\Sigma\left(\mathrm{w}\left(F_{\mathrm{o}}{ }^{2}-F_{\mathrm{c}}{ }^{2}\right)^{2}\right) / \Sigma(\mathrm{w}\right.$ $\left.\left.\left(F_{\mathrm{o}}\right)^{2}\right)\right]^{1 / 2}$. 


\section{Text for the Table of Contents}

Guanidinium 1-propynesulfonate (6) crystallizes with a "standard" single layer structure in which $\mathrm{CH}_{3} \mathrm{C} \equiv \mathrm{C}$ groups lie alternately above and below the mean plane of each sheet. Guanidinium ethynesulfonate (5) also crystallizes with a single layer stacking motif but, unlike 6, all the sheets have $\mathrm{HC} \equiv \mathrm{C}$ groups pointing in the same direction. $\mathrm{C}_{\mathrm{sp}}-\mathrm{H} \cdots \mathrm{O}$ hydrogen bonding between sulfonate anions is responsible for the unusual situation observed in $\mathbf{5}$.

Graphic for the Table of Contents, here 


\section{Keywords}

sulfonation $\bullet$ alkyne $\bullet$ crystal engineering $\bullet$ hydrogen bonding $\bullet$ guanidinium sulfonate 
Scheme 1

3D

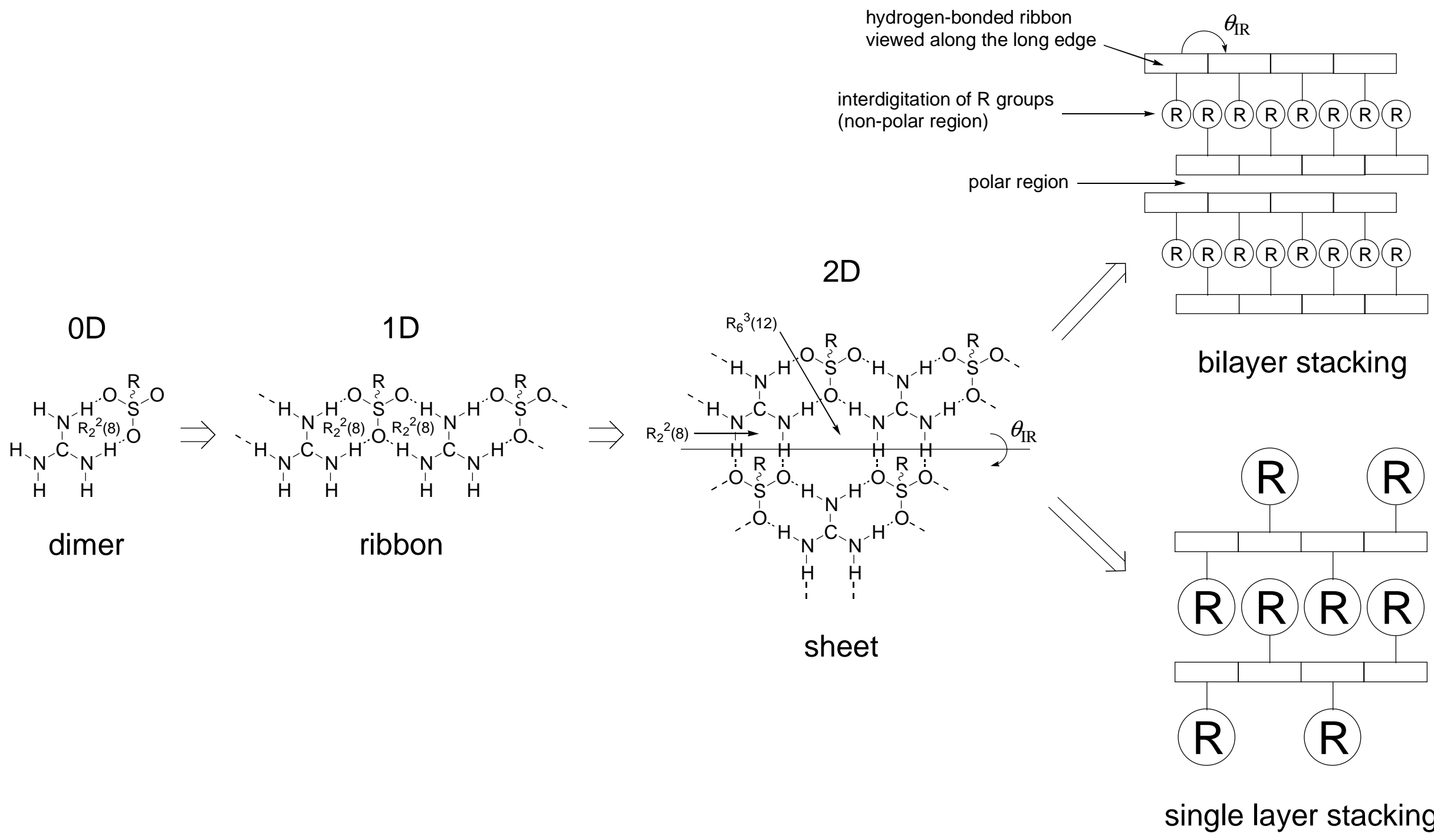


Scheme 2

$\mathrm{HC} \equiv \mathrm{CSiMe}_{3}+\mathrm{ClSO}_{3} \mathrm{SiMe}_{3} \stackrel{\mathrm{CH}_{2} \mathrm{Cl}_{2}}{\longrightarrow} \mathrm{HC} \equiv \mathrm{CSO}_{3} \mathrm{SiMe}_{3}+\mathrm{Me}_{3} \mathrm{SiCl}$

(1)

$\mathrm{CH}_{3} \mathrm{C} \equiv \mathrm{CSiMe}_{3}+\mathrm{SO}_{3}$.dioxane $\stackrel{\mathrm{CH}_{2} \mathrm{Cl}_{2}}{\longrightarrow} \mathrm{CH}_{3} \mathrm{C} \equiv \mathrm{CSO}_{3} \mathrm{SiMe}_{3}+$ dioxane

(2) 


\section{Scheme 3}

$$
\begin{aligned}
& \mathrm{RC} \equiv \mathrm{CSO}_{3} \mathrm{SiMe}_{3} \stackrel{\mathrm{H}_{2} \mathrm{O}}{\longrightarrow} \mathrm{RC} \equiv \mathrm{CSO}_{3} \mathrm{H} \cdot x \mathrm{H}_{2} \mathrm{O} \stackrel{1 / 2\left[{ }^{+} \mathrm{C}\left(\mathrm{NH}_{2}\right)_{3}\right]_{2} \mathrm{CO}_{3}{ }^{2-}}{\longrightarrow}\left[{ }^{+} \mathrm{C}\left(\mathrm{NH}_{2}\right)_{3}\right]\left[\mathrm{RC} \equiv \mathrm{CSO}_{3}{ }^{-}\right] \\
& \mathrm{R}=\mathrm{H}(\mathbf{1}) \\
& \mathrm{R}=\mathrm{CH}_{3}(2) \\
& \mathrm{R}=\mathrm{H}, \mathrm{x}=2.33 \text { (3) } \\
& \mathrm{R}=\mathrm{CH}_{3}, \mathrm{x}=1.88(4) \\
& \mathrm{R}=\mathrm{H}(5) \\
& \mathrm{R}=\mathrm{CH}_{3}(\mathbf{6})
\end{aligned}
$$


Figure 1

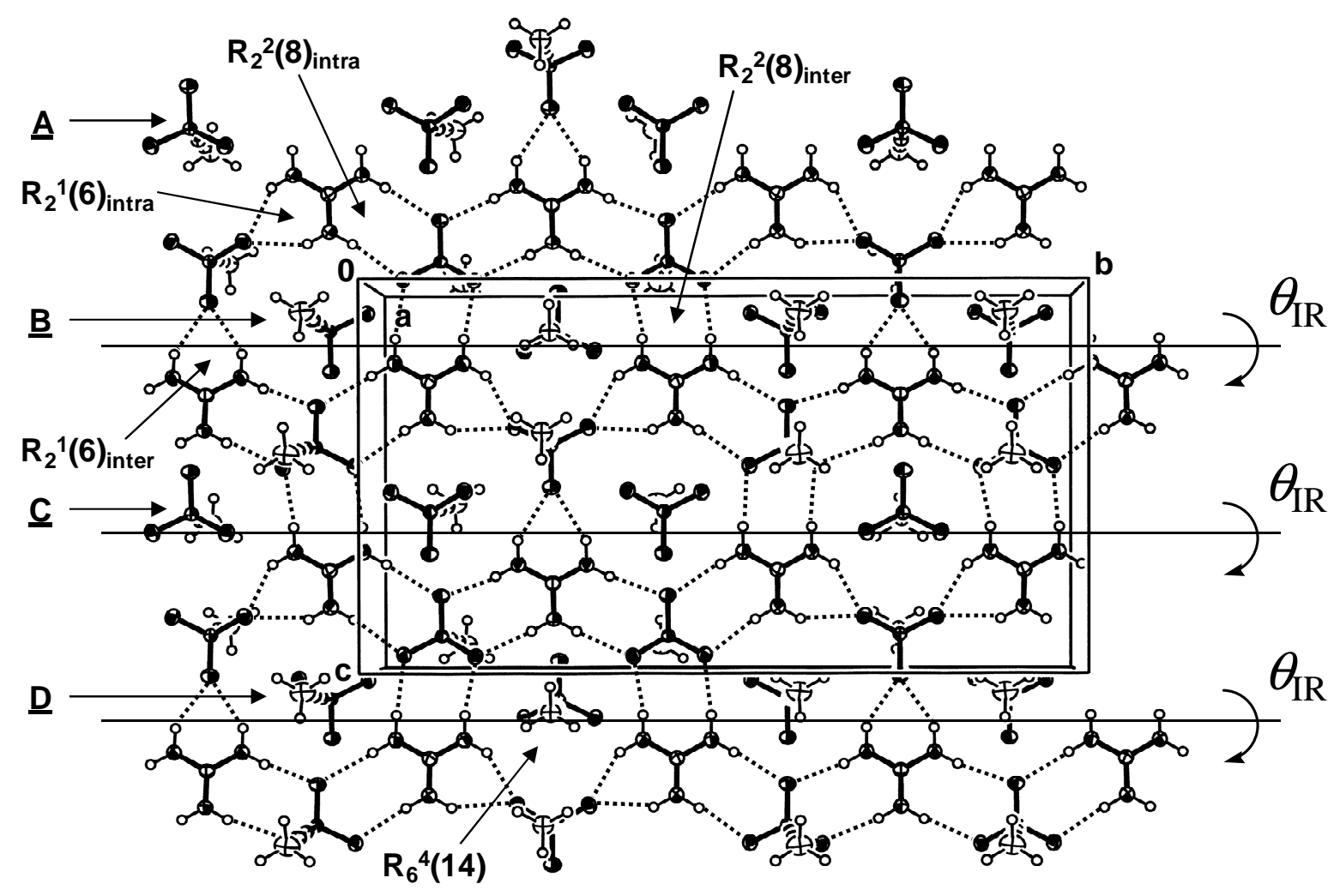


Figure 2

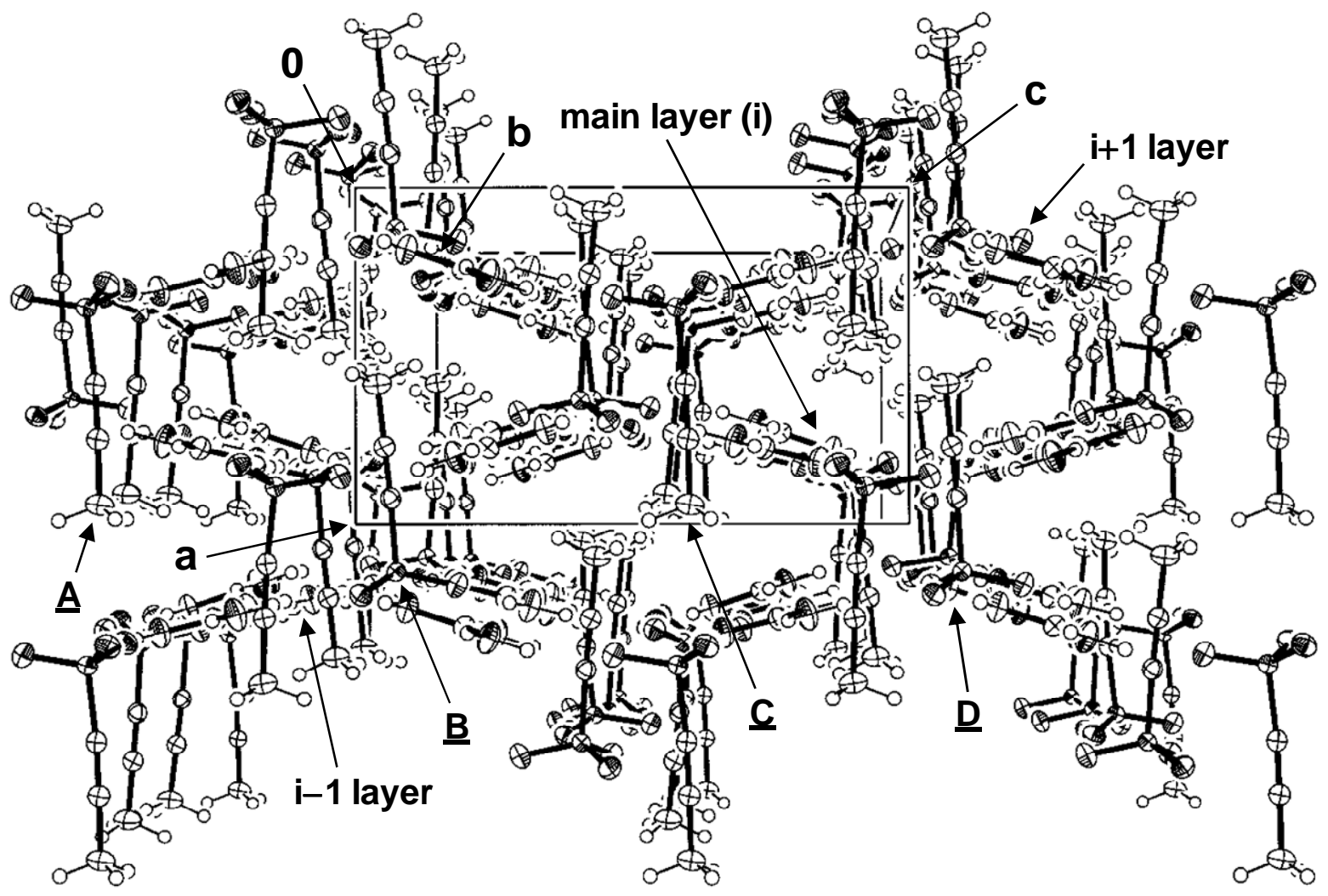


Figure 3

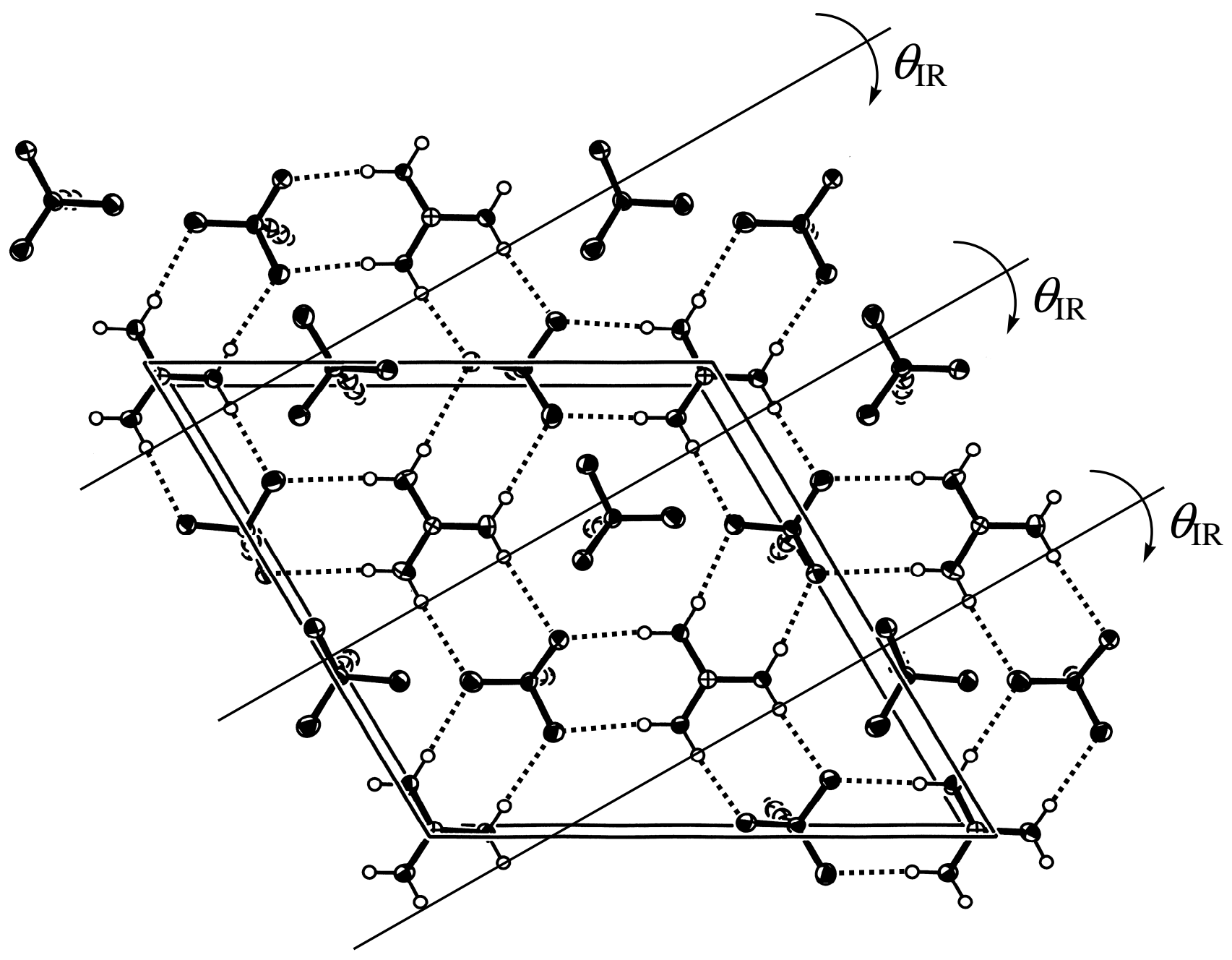


Figure 4

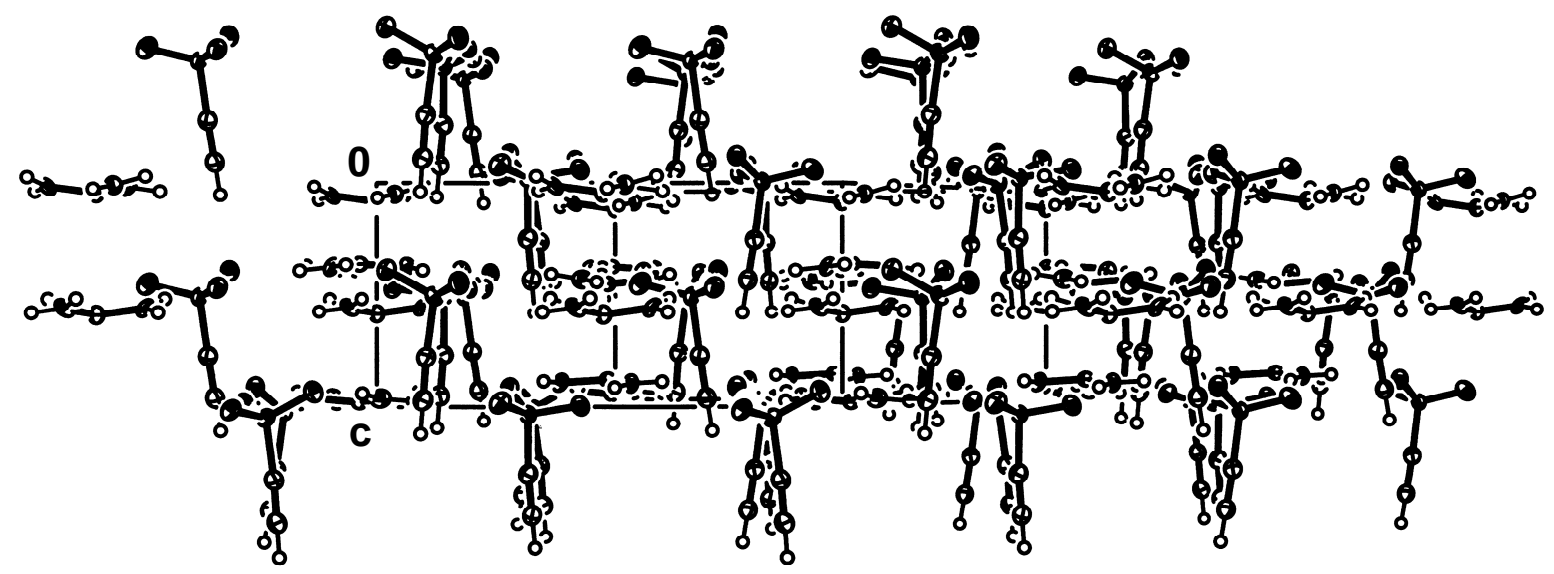


Figure 5

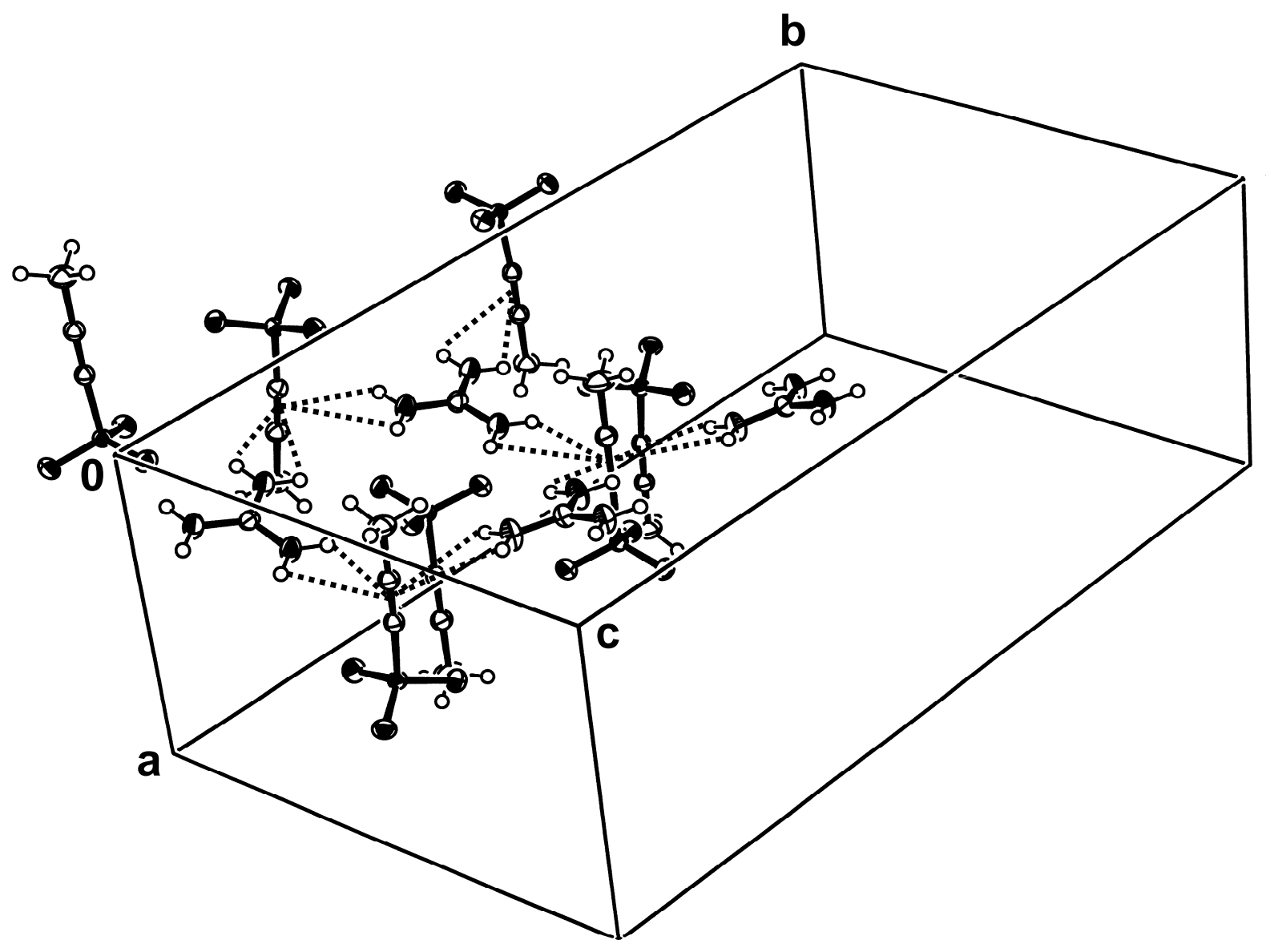


Figure 6

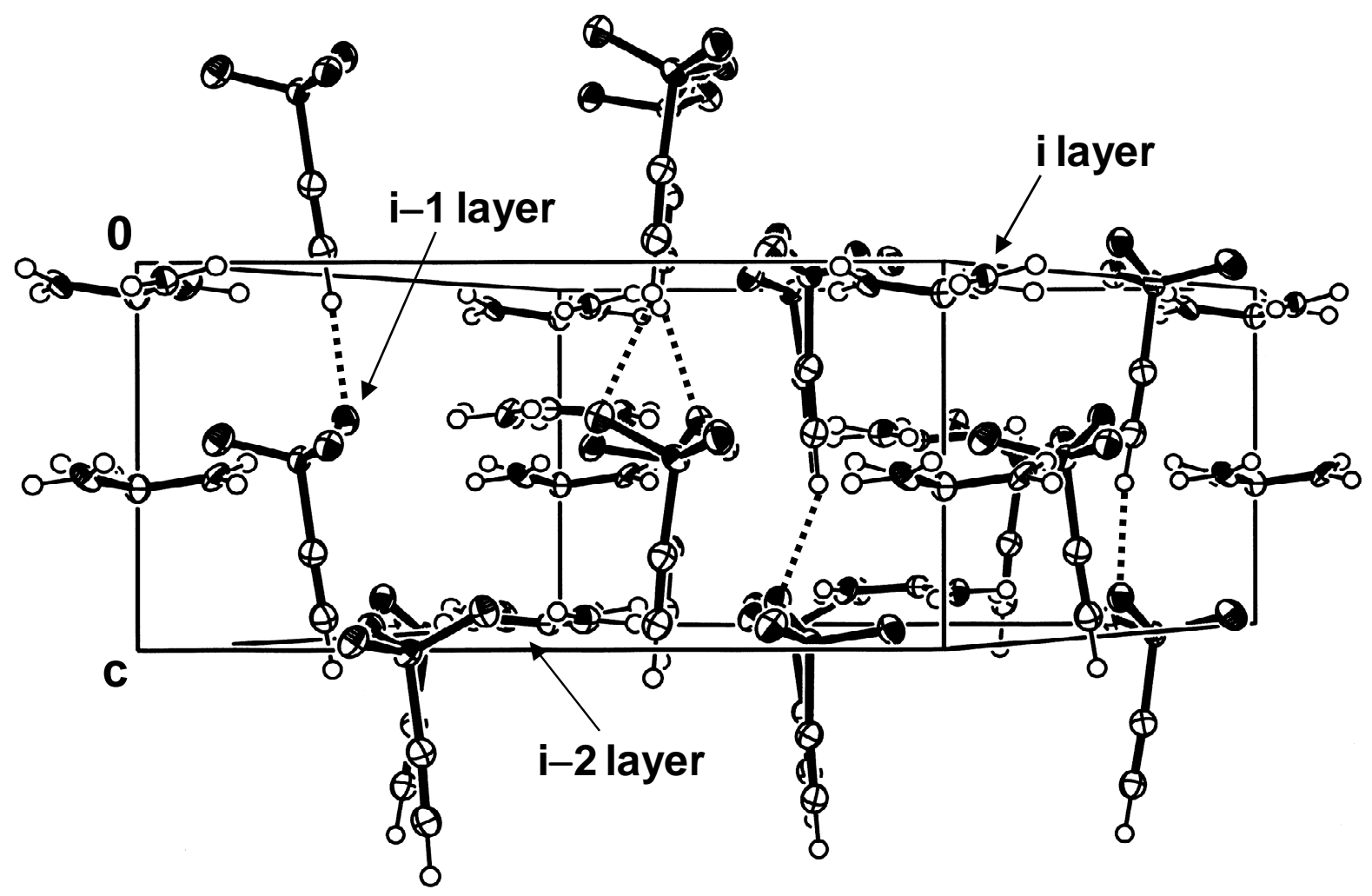

34 
Graphic for the Table of Contents
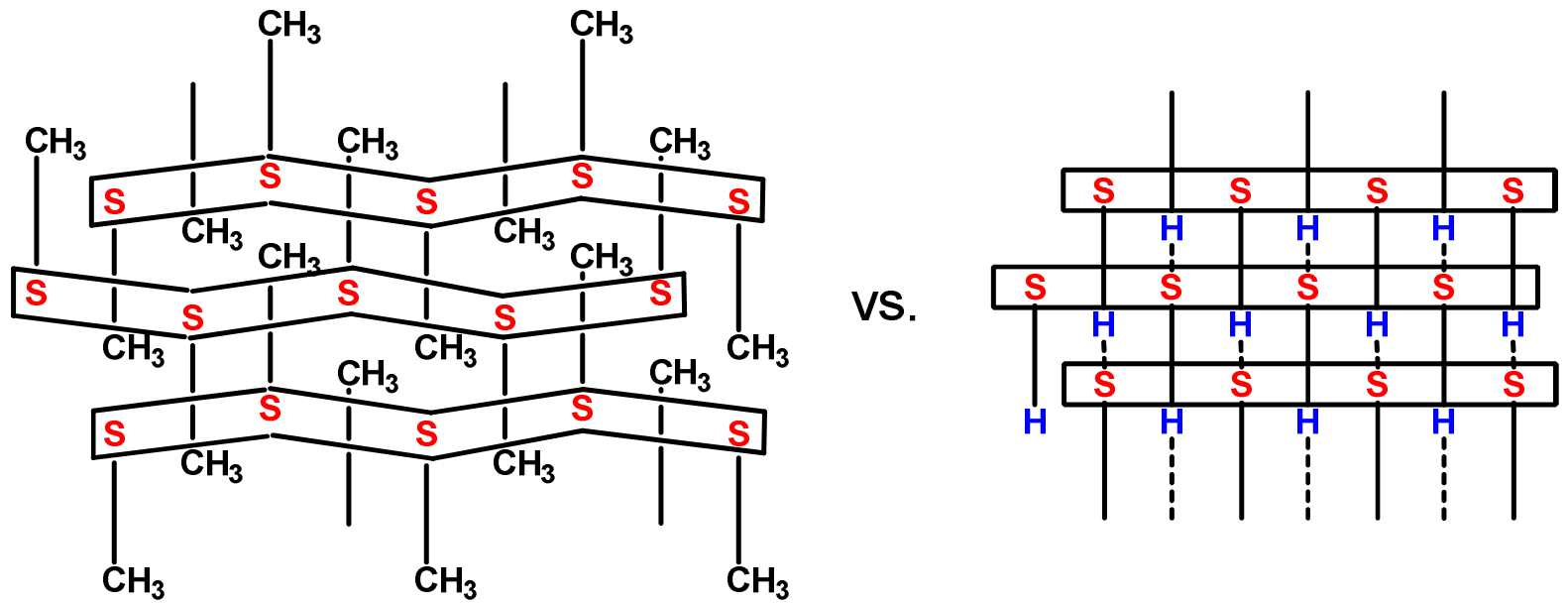